\title{
PALEOGENE IMBRICATE-LEAVED PODOCARPS FROM KING GEORGE ISLAND (ANTARCTICA): ASSESSING THE GEOLOGICAL CONTEXT AND BOTANICAL AFFINITIES
}

\author{
DAIANA FONTES \& TÂNIA LINDNER DUTRA \\ Programa de Pós-G raduação em G eologia, U niversidade do Vale do R io dos Sinos, Av. U nisinos, 950, 93022-000, São \\ Leopoldo, RS, Brasil.daianafontes@ hotmail.com, tdutra@unisinos.br
}

\begin{abstract}
A BSTRACT - Imbricate-leaved podocarps (D acrydium s.I.) are the dominant conifer remains in the U pper Cretaceous and Cenozoic successions of $K$ ing George Island, increasing its abundance in the post-L ate Pal eocene strata and maintained until the Early Oligocene times, with poor taphoflora registered in the last. However, a more precise taxonomic relationship of their remains was ever difficult given the fragmentary nature of the fossils and most known from ex situ material. In new field works and collections looking for the original levels, the recent phylogenetic approaches proposed and comparisons with extant floras have been applied to these fossils, and have helped to clarify their taxonomic status and their preferable association with the U pper Pal eocene-L ower E ocene levels. The two kinds of foliage discussed here initiated the taxonomic revision of the Podocarpaceae related fossils on the island and attest to a modern affinity with $D$ acrydium vel $H$ alocarpus and Dacrycarpus, which was in part proposed by previous works. Those genera comprise today an important component of the eastern Southern Hemisphere forests, and their occurrence in the A ntarctic Peninsula areas during the Paleogene supports a broader distribution in the past and attests to the importance of the ancient A ntarctic coastal areas in the modern distribution of the Podocarpaceae.
\end{abstract}

Key words: Dacrydium s.I., D acrycarpus, Lower Eocene, K ing George Island, A ntarctic Peninsula.

RESU M O - As Podocarpaceae são o principal grupo de coníferas nas floras do C retáceo-Paleógeno da ilha K ing George, Península A ntártica e, após o final do Paleoceno, tipos dotados de folhas pequenas e imbricadas, inicial mente agrupados em Dacrydium s.l., passam a ser dominantes nas assembléias. 0 caráter incompleto dos fósseis, que dificulta uma atribuição taxonômica mais precisa, fez também com que este epíteto genérico, sem afinidades filogenéticas bem estabelecidas, fosse muito utilizado nos primeiros estudos feitos. N ovas análises e a ampliação das coletas, embora não tenham solucionado de todo este problema, mostraram ser úteis para tornar mais precisos os tipos de Podocarpaceae presentes. N este trabalho, dois morfotipos são revistos e sugerida sua afinidade preferencial com Dacrydium vel Halocarpus e Dacrycarpus, hoje importantes componentes dos biomas do setor oriental do H emisfério Sul. São igual mente localizados de modo mais preciso e a partir de novos trabalhos de campo, os níveis com plantas do M onte Wawel (= Pontal Hennequin), na baía do A Imirantado, previamente conhecidos a partir de material ex situ, o que permitiu propor uma idade Eoceno Inferior para estes depósitos. A presença destes gêneros de Podocarpaceae em áreas da Península A ntártica durante o Cenofítico, não apenas confirma sua ocorrência mais ampla no passado, como o importante papel exercido pelas áreas costeiras da A ntártica na moderna distribuição da família.

Palavras-chave: Dacrydium s.I., Dacrycarpus, Eoceno Inferior, ilha King George, Península A ntártica.

\section{INTRODUCTION}

A great diversity of fossil plants has been collected from King George I sland (K GI), South Shetland I slands, A ntarctic Peninsula (Figure 1 ). $M$ any of the taxa found are coniferous and include the A raucariaceae and Cupressaceae, but by far, the most abundant are those with affinities to the Podocarpaceae (Birkenmajer \& Zastawniak, 1989; Zhang Shanzen \& Wang Qingzhi, 1994; Zhou Zhian \& Li Haomin, 1994a).

Podocarpaceous foliage compressions and impressions have also been found in fossil assemblages across the Southern Hemisphere, since their first remains were discovered in the $19^{\text {th }}$ century. They have often been assigned to two broad and informal taxa based on the arrangement and size of theleaves, Podocarpus s.I. and Dacrydium s.l. (Philippi, 1861; Florin, 1931; de Laubenfels, 1969). This taxonomic treatment was still applied to extant groups until the 1980s and sometimes used in the determination of the scarce and incomplete plant fossil material, such as those found in most of the K GI fossil assemblages (Zastawniak, 1981; Zastawniak et al., 1985).

The identification of new fossil material in A ustralia and New Zealand, some associated with reproductive structures and cuticles (Wells \& Hill, 1989; Hill \& Carpenter, 1991; Pole, 1992; J ordan, 1995; H ill \& Christophel, 2001), allows advances 
in the taxonomic placement of podocarpaceous fossils (Hill $\&$ B rodribb, 2003), also with the help of the re-evaluations in taxonomy and phylogeny of extant Podocarpaceae (Quinn, 1982; Chaw et al., 2000; K elch, 1998). A long geological history for the Podocarpaceae and a monophyletic origin emerges from those works, in common with that from the Taxodiaceae and Cephalotaxaceae, and with a close relation with the A raucariaceae.

The Podocarpaceae probably originated at the end of the Paleozoic, and by the Triassic they are evidenced by Rissikia and M ataia from Chile, A ustralia, New Zealand and South A frica (Townrow, 1967; A nderson et al., 2007; Herbst et al., 2005), and in the pollen assemblages (Podocarpidites and Dacrycarpites) from the northwestern A rgentina area (Zavattieri, 1990). In the uppermost Triassic, cuticles with a podocarpoid character were found associated with conifer shoots in southern Brazil (Dutra \& Wilberger, 2010). The Triassic shoots (Rissikianthus), cones (Rissikistrobus) and wood (Notophytum krauseli) identified in the Fremouw Formation al so confirms A ntarctica as an important location in the family's first appearances ( $M$ eyer-B erthaud $\&$ Taylor, 1991; A xsmith et al., 1998).

The Podocarpaceae maintained a dominant austral distribution throughout the J urassic and at the beginning of the Cretaceous, and advanced into more tropical latitudes, taking advantage of the equable warm climatic conditions and the continuous landmass of Pangaea (Pearson et al., 2001), to finally reach the $\mathrm{N}$ orthern $\mathrm{H}$ emisphere ( $\mathrm{M}$ ill, 2003; Fontes, 2008). During the C retaceous, the first modern rel ated forms appeared in the South A merica-A ntarctic region, both in macroassemblages and pollen grains (Halle, 1913; Romero \& A rguijo, 1981; A skin, 1990; Cao L iu, 1992; Zhou Zhian \& Li Haomin, 1994b; Dutra \& B atten, 2000; Francis et al., 2008).

During the Cenozoic, the group maintained its southern high latitude distribution, mainly during the warm intervals of the Pal eocene-EoceneThermal M aximum (PETM ) and Early Eocene Climatic O ptimum (EECO), between 55 and $52 \mathrm{M} \mathrm{a}$ (Zachos et al., 2003; Shellito et al., 2003). The worldwide distribution is preserved until the beginning of the N eogene, when $\mathrm{A}$ ntarctic isolation and $\mathrm{CO}_{2}$ decrease resulted in a global climatic cooling and restriction of high latitude biomes (Zachos et al., 2001; F rancis et al ., 2008). The Podocarpaceae seemed less affected by these low temperatures than other austral conifers and were thus able to persist for a relatively long period in high latitudes, including the South Pole area (Francis \& Hill, 1996). A ccording to Pole (2001) and Winkworth et al. (2002), the diversity shown by the podocarps during the Late Cenozoic and today in $\mathrm{New}$ Zeal and results from secondary radiations, and long distance dispersal occurred at specific times during their geological history.

Today, the family represents the largest and most diversified group of conifers, growing mainly in altitudinal mesic forests, either mixed with angiosperms or in nearly pure stands (Quinn \& Price, 2003). In colder latitudes down to coastal areas, such as on South I sland of N ew Zealand, they experienced oceanic climates (E ckenwal der, 2009). Podocarps with scale-like leaves on the mature shoots can al so endure extreme cold, forming pure stands in localities of periodically frozen soils, where could adopt dwarf habits, such the New Zealand and Tasmanian H alocarpus bidwillii (Hook ex K irk) Quinn and Microcachrys Hooker fil., and the South A merican Lepidothamnus fonkii Philippi (Veblen et al., 1995; Wells \& Hill, 1989; Echkenwalder, 2009). The characters proffered by diversified adaptations, with varied shoot morphologies, attest to the plasticity of their foliage. The ability of the Podocarpaceae for long-distance dispersal probably guaranteed long-term survival and wide distribution during geological time (Cubitt \& M olloy, 1994; Pole, 2001). These ecological and behavioral aspects support the proposal of Brodribb \& Hill (2003) that extreme dry conditions are the only limiting factor to the development and spread of the Podocarpaceae.

In this work, Pal eogene imbricate-leaved podocarps from K ing G eorge I sland (A ntartica), some originating from newly collected in-situ specimens and exhibiting two types of leaf shoots are described and rediscussed in relation to their taxonomic and stratigraphic placement.

\section{Podocarpaceous leaf shoots and taxonomic affinities}

The Podocarpaceae have perennial and sclerophyllous foliage, a character that increases their preservation potential and makes them a common feature of the fossil record, especially originating from ancient disturbed areas ( $F$ alconL ang \& C antrill, 2001). The leaves are spirally arranged and generally simple, entire and decurrent, a morphology that hel ps in a broad selection and to distinguish them from fossils of other southern conifer remains, such as the Cupressaceae, normally exhibiting whorled phyllotaxis with opposite or decussate leaves (Offler, 1984) and the A raucariaceae, where in similar needle-like leaved shoots the presence of a detached midvein is not common. Yet, higher order (intrafamilial) distinction is often difficult using shoot arrangement and size of leaves alone, since many genera can appear similar (e.g. opposite leaf insertion can be found in the podocarp of $M$ icrocachrys and whorled phyllotaxis in some Podocarpus; Offler, 1984; Hill, 1998).

H owever, within the Podocarpaceae, leaf characters have been used to separate two main groups, Podocarpus s.l. (Philippi, 1861), with leaf shoots composed of large, openarranged needle-like leaves, with one central vein and a common false petiole, and Dacrydium s.l., characterized by strongly adpressed, short, imbricate and bifacial flattened leaves, especially in the mature shoots (Offler, 1984; Wells \& Hill, 1989; Stockey, 1990; Pole, 1992). The first one includes, for example, Podocarpus s.S., Acmopyle Pilger, Afrocarpus Page and Nageia Gaertn, the last distinct in maintaining a great number of veins over the leaf, a plesi omorphic character according to K elch (1998). The determination of D acrydium s.l. foliage, to which the material presented here refers, is more complex due to the heterophillic character of the shoots in some genera, with mature ones bearing short and imbricate leaves associated with spreading linear ones, or young trees with needle-like sharply pointed subfalcate leaves, which may give rise to small scale-like and closely adpresssed leaves in the adult foliage (e.g. Halocarpus and Dacrydium).

Florin (1931) divided Dacrydium s.l. into sections A, B and $C$ based on leaf shoot and cuticle characters. D acrydium 
S.S. was retained in section $B$, whilst Lepidothamnus Philippi, Lagarostrobos Quinn and Halocarpus Quinn were grouped together in section $C$ based mainly on the morphology of reproductive structures (de L aubenfels, 1969; Q uinn \& Gadek, 1981; Quinn, 1982). Molloy (1995) created a fourth monospecific genus, Manoao, by segregating the species Lagarostrobus colensoi. Strong support for the work of Quinn (1982) is provided by other independent studies, such as those of leaf epidermal structures, wood anatomy and pollen morphology (Florin, 1931; Patel, 1967; Pocknall, 1981). $M$ ore recent molecular studies confirm the polyphyletic origin of Dacrydium s.l. (K elch, 1998; Page, 1999; Chaw et al., 2000).

\section{THE KING GEORGE ISLAND GEOLOGICAL SETTING AND KNOWN TAPHOFLORAS}

On K ing G eorge Island (K GI), two areas are renowned for the presence of diversified and abundant $L$ ate $C$ retaceous to Early N eogene plant fossil assemblages: the Fildes Peninsula and A dmi ralty B ay (Birkenmajer \& Zastawniak, 1989; Wang Yinxi \& Shen Yanbin, 1994; see Figure 1). The complex geological context of the island is due to a genesis in a fore arc tectonic region, and coupled with ice cover, which has hindered the determination of a more regional stratigraphic framework and correlations between the fossil plant beds (Smellie et al., 1984; Y anbin, 1994; B irkenmajer, 2001; Dutra, 2004).

On Fildes Peninsula, the first and most widely studied plant fossil succession is that exposed at the top of Fossil

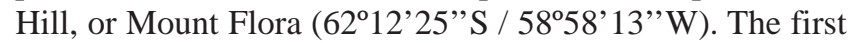
stratigraphic description of this local ity was by Smellie et al. (1984), later detailed by Shen Yanbin (1994). Plant fossil assemblages from Fossil Hill were first published by O rlando (1964) and Troncoso (1986), and more intensive collections and systematic studies allowed the founding of at least nine distinct sub-localities (Czajkowski \& Rösler, 1986; Torres \& M éon, 1990; Cao L iu, 1992; Y anbin, 1994; Zhiyan \& Haomin, 1994a,b; Shanzen \& Qingzhi, 1994; Dutra \& Batten, 2000; H unt \& Poole, 2003; Dutra, 2004), each yielding both a microand macroflora, and confirming those floras of F ossil Hill as the most diversified and best preserved ones (Figure 2). The assemblage is made up of angiosperms, with rare but large, broad-leaf types of Nothofagus, many ferns, and distinct gymnosperms, with a dominant podocarp component, alongside Cupressaceae and A raucariaceae (Fontes, 2008).

A $n$ Upper Paleocene or Lower Eocene age was suggested from palynological studies (Cao, 1992) and R b$\mathrm{Sr}$ radiometric age data of 58 to $52 \mathrm{M}$ a obtained on the basal andesitic lavas that were recovered by agglomerates and by the volcanoclastic fining-upward succession that contains the plant fossil remains ( $\mathrm{L}$ i et al., 1989). The beds were included in the basal part of the Fossil Hill Formation by Yanbin (1994), corresponding to Fildes Formation from Smellie et al. (1984).

Within the Fossil Hill outcrop the Podocarpaceae are represented by shoot impressions (Zhiyan \& H aomin, 1994a; Fontes, 2008) in a succession that also includes levels with probable impressions of syneresis cracks and the until now exclusive evidence of a vertebrate life in the island, represented by bird ichnites belonging to the Ratites ( $\mathrm{Li} \&$ Zhen, 1994), which suggests a deposition on shallow lakes and the rework of volcaniclastic grains by drainages. A second locality on Fildes Peninsula, the Collins G lacier locality, al so of a Late Paleocene and/or Early Eocene age, yields many

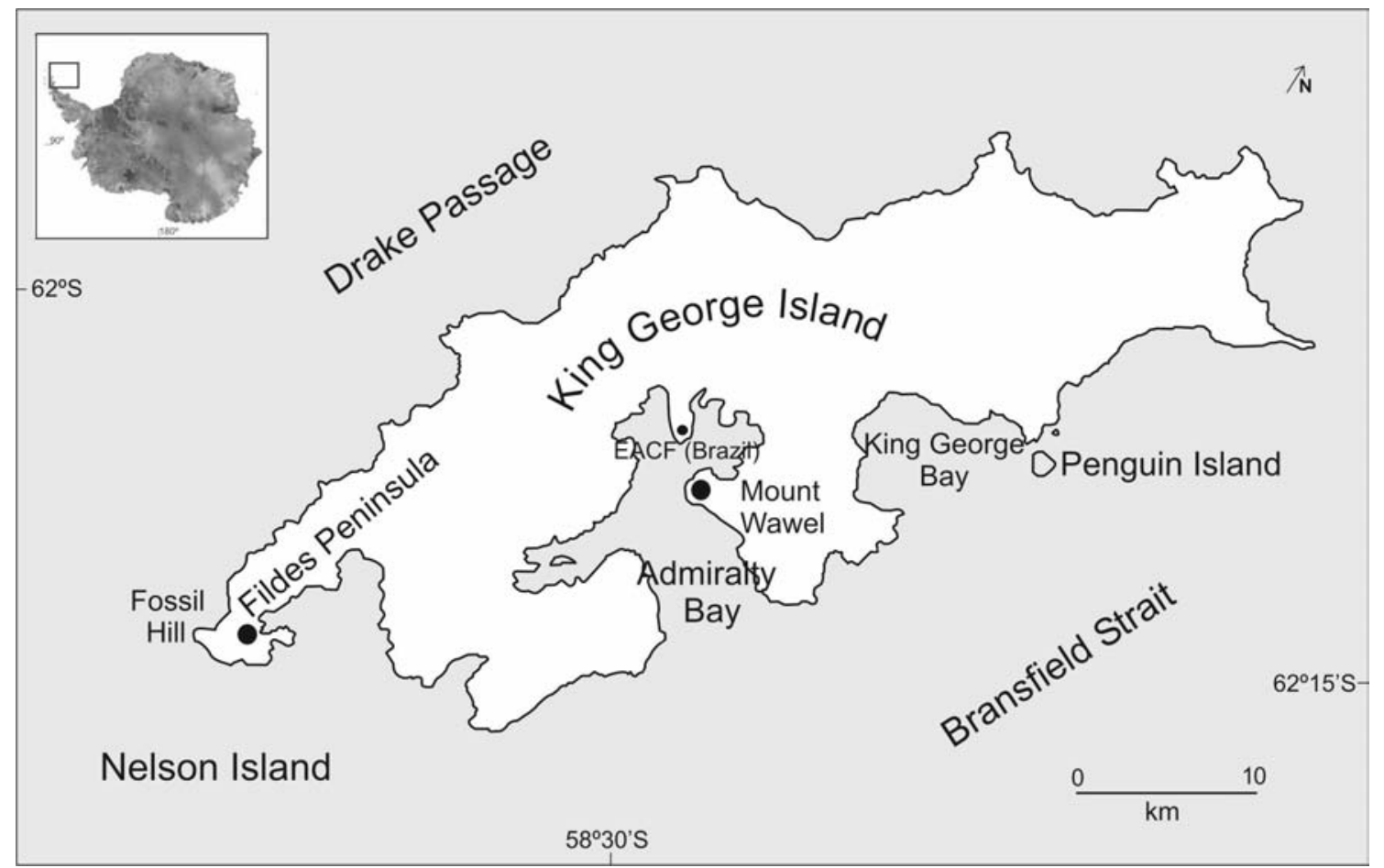

Figure 1. Map of King George Island, showing the main plant fossil localities, Fildes Peninsula and Admiralty Bay. Large dots indicate where podocarpaceous remains have been found. 
pieces of fossil wood that include a high podocarp component (Shanzen \& Qingzhi, 1994).

In A dmiral ty B ay, the first geological investigations were undertaken by Hawkes (1961) and B arton (1965), followed by the Polish works coordinated by B irkenmajer, which proposed a more formal stratigraphy for the area (B irkenmajer, 2001). The richest plant fossil assemblage there, and the only one until now, known to preserve podocarp leaf shoots (Zastawniak, 1981; Zastawniak et al., 1985; Poole et al., 2001; Hunt \& Poole, 2003), comes from strata al ong the slopes of the Mount Wawel or Point Hennequin $\left(62^{\circ} 07^{\prime} 00^{\prime \prime} \mathrm{S} /\right.$ $58^{\circ} 24^{\prime} 00^{\prime \prime} \mathrm{W}$ ) and was considered to be Lower M iocene in age (B irkenmajer, 2001). The succession, included in the Point Hennequin Group of Hawkes (1961), is exposed at M ount
Wawel (Figure 3) and comprises andesitic lava flows (eleven were measured by Barton, 1965), breccias and Iapilli, also intercalated by few and thin levels of reworked volcanic material. Birkenmajer (2001) considered that two distinct episodes of tectonic and volcanic activity were preserved in the lava pile, and proposed distinct units, the Vièville Glacier and the M ount Wawel formations, with ages varying, respectively, between 44-47 M a and 27-24.5 M a (Pankhurst\& Smellie, 1983; Smellie et al., 1984; B irkenmajer et al., 1986).

The fossils are associated with distinct facies on the 300 $\mathrm{m}$ high exposure, greatly affected by the faulting and ice covering and reworking. For a long time, this condition prevented the exact understanding of their original location, as they are found in moraine blocks over the low and mid

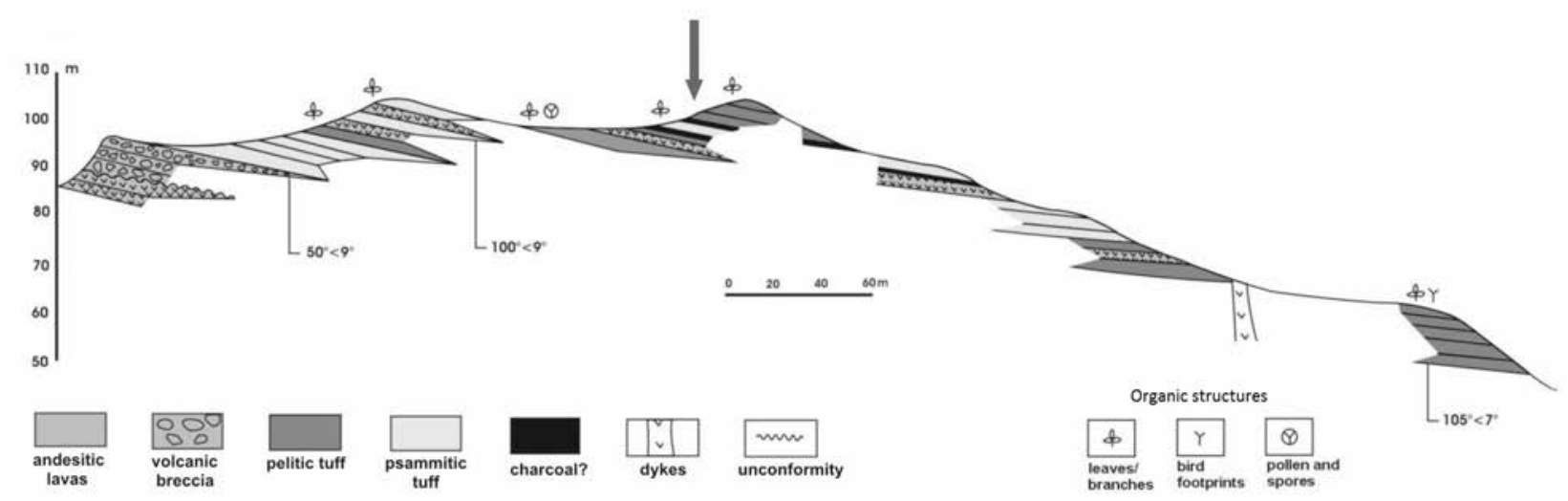

Figure 2. Transection through the top of Fossil Hill (Fossil Hill Formation from Li et al., 1989), on Fildes Peninsula, and the relative positions of the fossiliferous horizons (modified from Yanbin, 1994). The arrow indicates the volcanoclastic beds with concentrated podocarp remains.

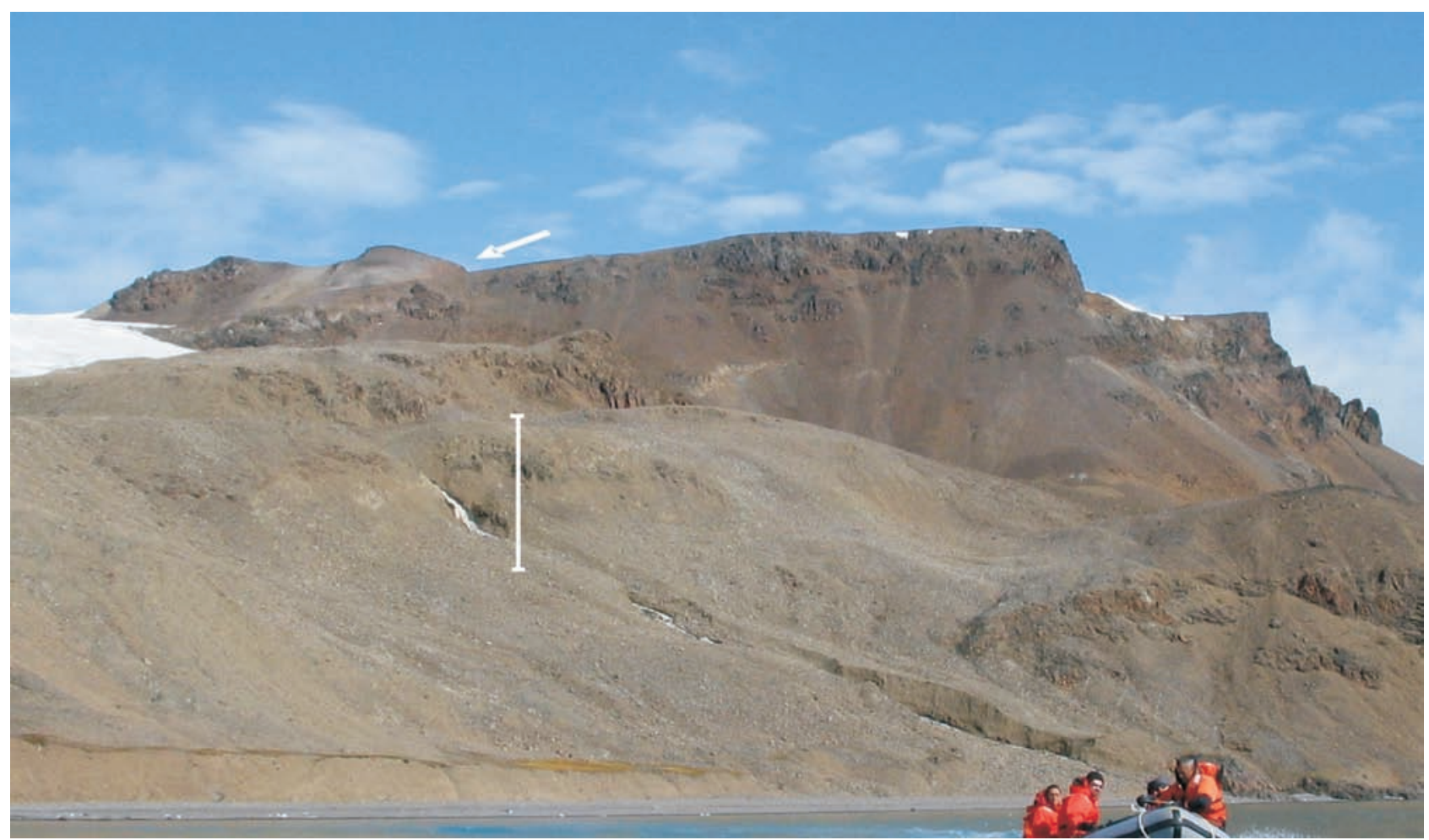

Figure 3. General view of the Mount Wawel, Admiralty Bay, with the location of the main fossil plant beds indicated by vertical line on the middle slope. The arrow points to the position of the only known in-situ "Mount Wawel plant beds" until 2007 (Zastawniak, 1981 ; Zastawniak et al., 1985). 
slopes of the hill. Only one level at the top of the sequence was considered to be in-situ and has been termed the "M ount Wawel plant fossils beds" by Zastawniak (1981). The other ex-situ blocks have been referred to as the "Dragon and Wanda Glacier fossil plants beds" and "Smok plant fossil beds" (B irkenmajer, 2001; Hunt \& Poole, 2003; Dutra, 2004). According to Zastawniak et al. (1985), the origin of the exsitu plant fossil beds was the same from the in situ occurrences and designated the beds of the Mount Wawel Formation from B irkenmajer (2001), which guaranteed a L ate Oligocene age.

Investigations undertaken across M ount Wawel coupled with an extensive melting of the ice cover in the 2006-2007 summer season, allowed a better establishment of the fossil succession, such that in the mid altitude plants, beds from which part of the ex-situ material was originated (Figure 4). Resulting from this, the most basal fossiliferous bed were shown to be the origin of the samples formerly attributed to "D ragon G lacier plant beds" (level A, Figure 4), composed of yellowish, green and brown finely laminated psammitic to pelitic reworked tuffs, deposited in many fining-upward repeating cycles ("varves" of B irkenmajer, 2001). There, the Podocarpaceae represent $56 \%$ of the total gymnosperms preserved - a composition similar to that found at Fossil Hill - and influenced the high diversity index (4.7) obtained in the taphoflora. These lower beds are also characterized by the presence of bioturbation, small and thin pavements marked by probable syneresis cracks and raindrop impressions, suggesting ephemeral water bodies, as suggested

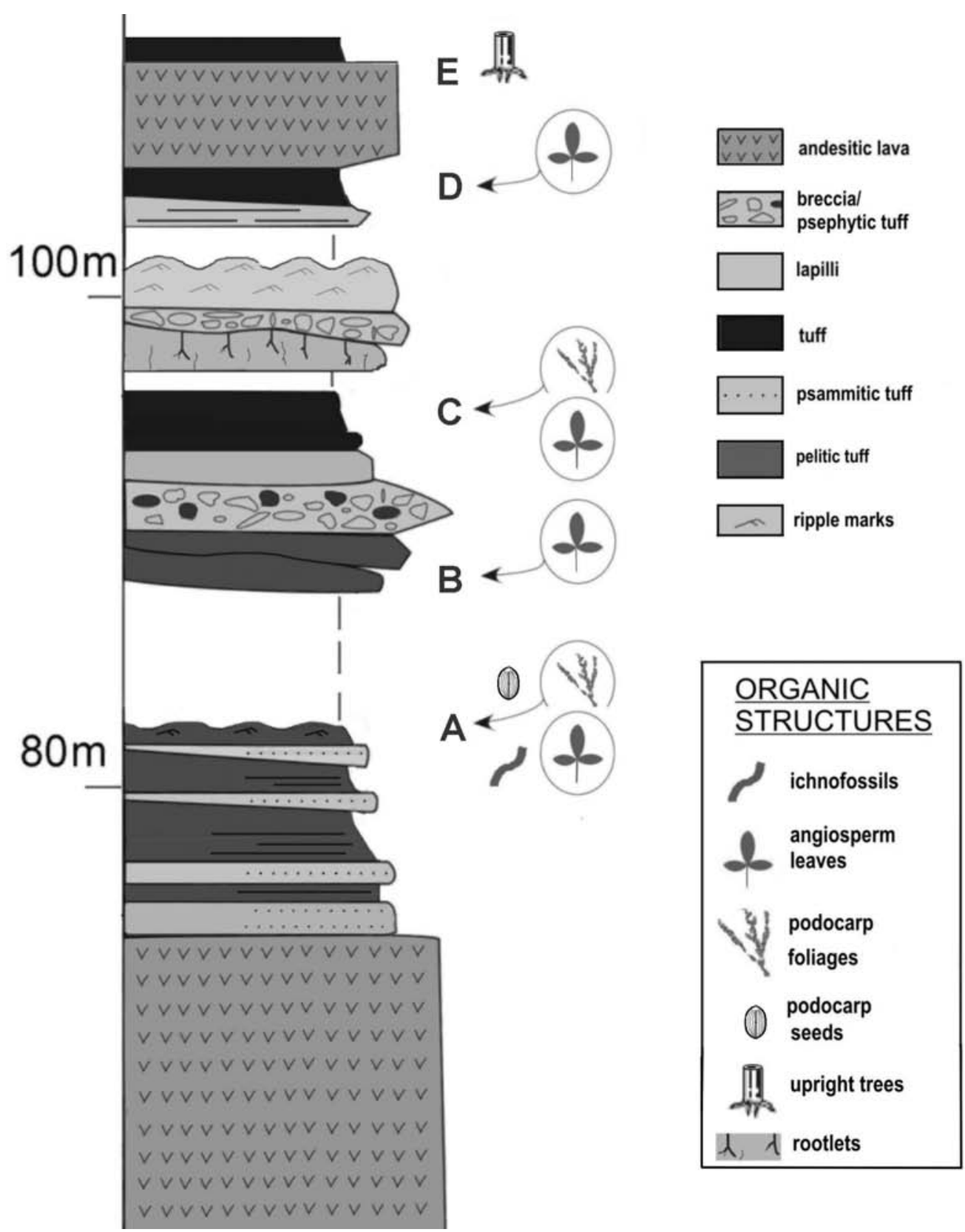

Figure 4. Vertical section from the middle slope of Mount Wawel, with the relative position of the fossil levels described herein. Levels A, B and C correspond to what was called "Dragon Glacier Plant Beds" in previous works; level D to the former beds indicate to "Wanda Glacier Plant Beds"; level E to that referred to "Smok Plant Beds". 
by Birkenmajer (2001). M any small, isolated shoots, leaves and seeds of Podocarpaceae and other gymnosperms (including A raucariaceae), along with fern pinnules and broadleaves of Nothofagus, were linked to these levels (Zastawniak, 1981; Fontes, 2008).

Overlying these basal beds and above an unknown interval still covered by ice and moraine material, level $B$ is exposed (Figure 4), composed of dark-brown to grey tuffaceous lapilli, containing poorly preserved angiosperm remains. It is followed by a thick, fining upward succession of dominantly green to yellow and red-green rocks composed of successive levels of agglomerate, lapilli and tuff (level C), and where the upper beds yield a diverse and well-preserved dark-red angiosperm leaves and podocarp shoots. The plant material and lithologies correspond to those described as the "Wanda G lacier plant beds" of B irkenmajer (2001). Within some levels, the plant remains exhibit a unidirectional orientation supporting the idea that they were al so laid down in shallow, ephemeral streams (Figure 5). Ex-situ beds found at the same altitude allow seeing pavements formed by the rew orked volcanic grains and asymmetrical wave ripples (Figure 6). Other pavements exhibit interference ripples with isolated Nothofagus leaves with similar genesis, representing the shallow water body supplied by the fluvial streams. Similar depositional structures and preserved plants were previously identified in this local ity by Dutra (2001) and Hunt \& Poole (2003) and referred to as "Smok Hill plant beds."

L evel $D$ begins with reworked green massive psammites with a conspicuous root horizon ( 20 to $10 \mathrm{~cm}$ high) followed by sterile psammitic tuff layer with high-angle cross stratifications, suggestive of surge deposits. This then grades into a cyclic deposition of grey to dark-grey fining upward tuff, representing ash fall deposits (Pereira et al., 2003). Their uppermost layers are covered by isolated and dispersed microphyllic and toothed leaves of Nothofagus and Sapindaceae (aff. C upania grosse-serrata B erry), which was also found in the dispersed samples of the "Smok Hill plant bed" by Dutra (2001) and Hunt \& Poole (2003). The fossil succession ends with an autochthonous occurrence of charcolified wood located at an altitude of nearly 100 to 120 m (Figure 4, level D).

The discussed fossil content, mainly those from basal levels, marked by a higher floristic diversity, biogenic structures (ichnofossils), and reworked volcanic debris, seems to agree better with those occurring in other sectors of the island, where the ages proposed for the Vièville G lacier Formation (47-44 M a) seems to be more coherent, than that indicated for the M ount Wawel Formation (27-24 M a). A s a consequence, it prevents at this moment the inclusion of the succession studied, in the formal stratigraphy proposed for Point Hennequin or Mount

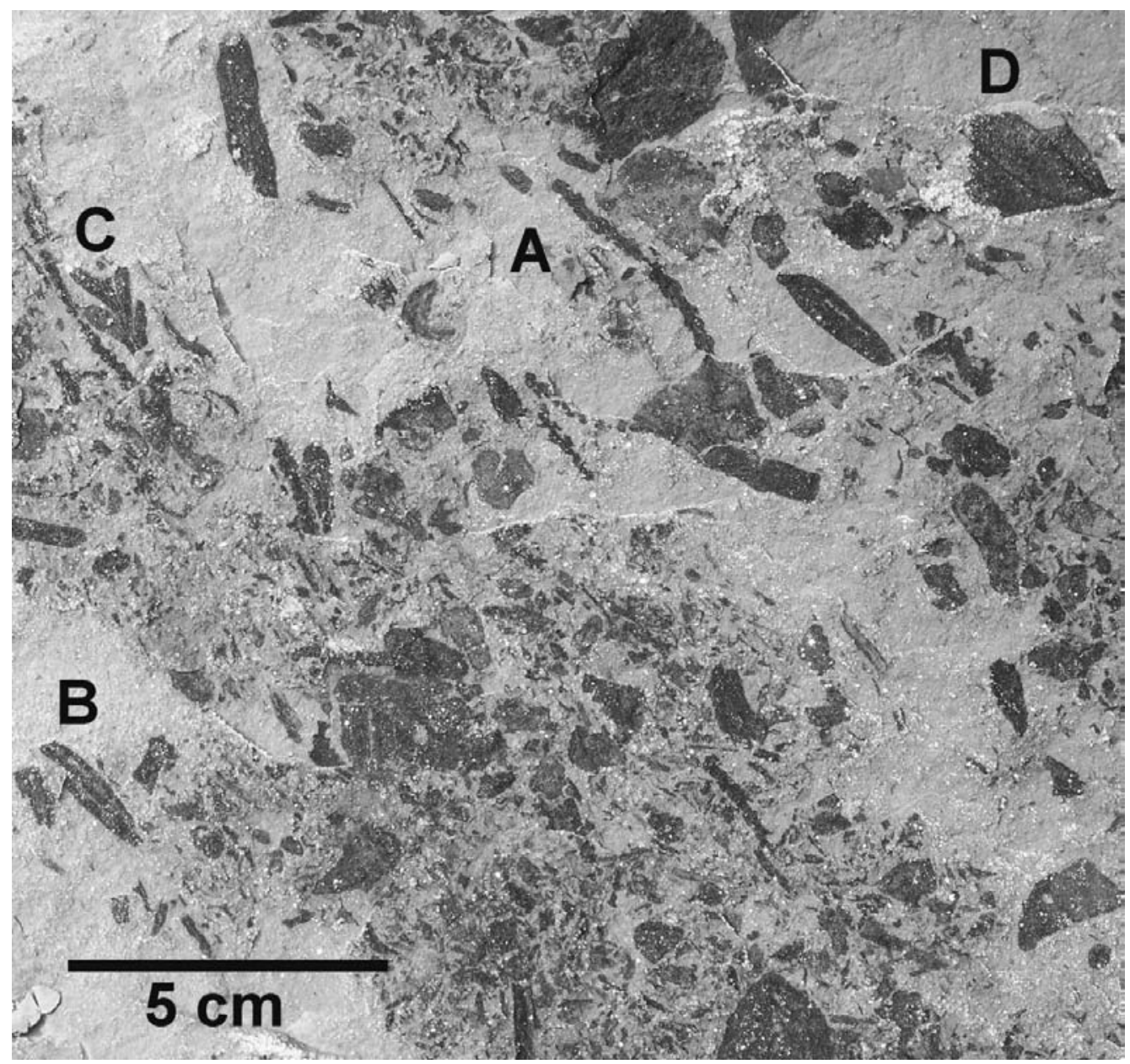

Figure 5. Organic in the Mount Wawel deposits. A-D, highly fragmented plant fossil remains, exhibiting a unidirectional orientation, from the more basal beds of level C (see Figure 4), supporting river stream deposition: A, scale-like leaf shoots of Dacrydium s.l.; B, isolated leaves of Podocarpus s.l., with its characteristic central vein; C, fern pinnules; D, parts of Nothofagus leaves. 


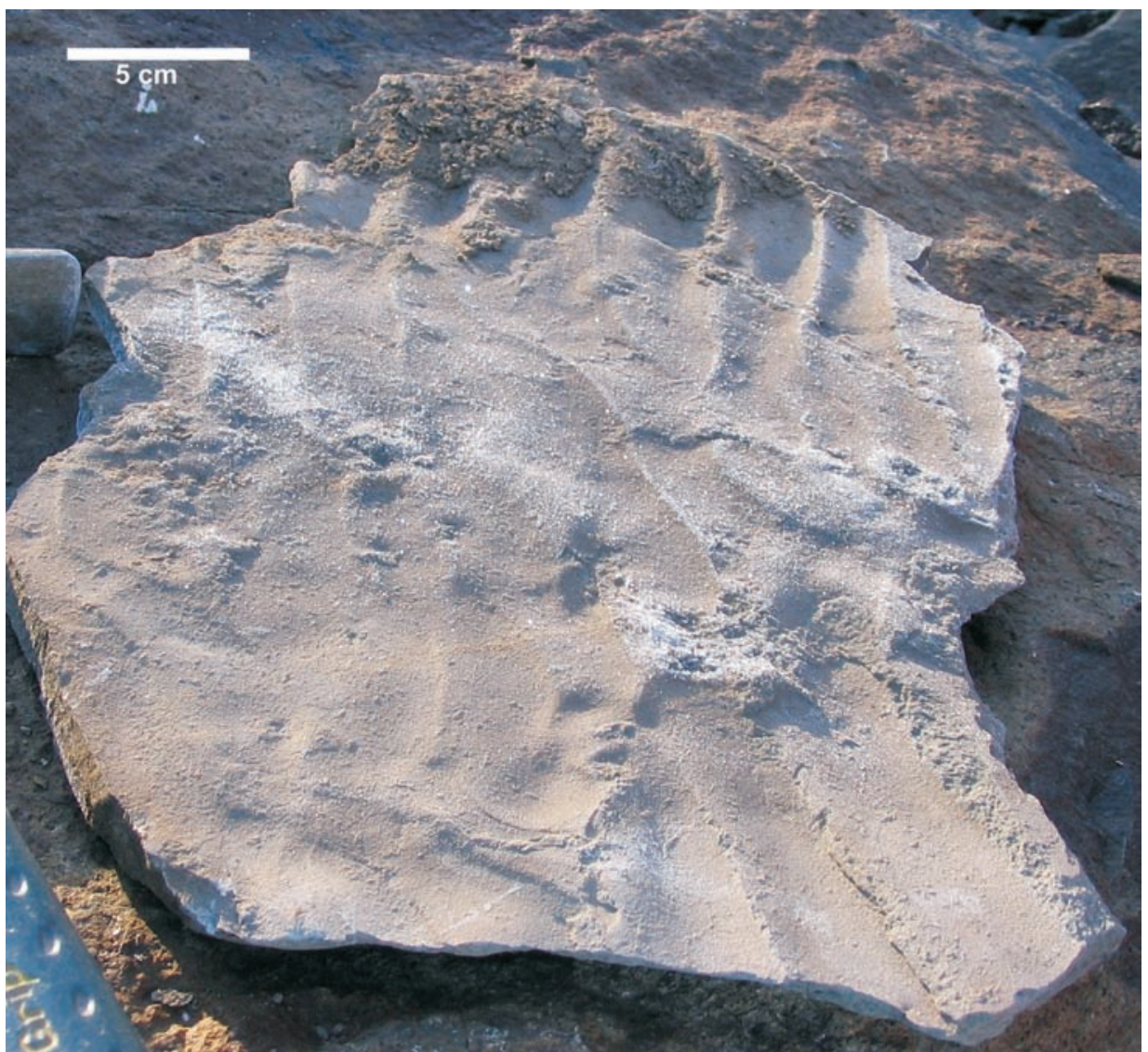

Figure 6. Sedimentary structures in the Mount Wawel deposits. Pavement with asymmetrical wave ripples found on the surface of moraine blocks.

Wawel by Birkenmajer (2001), but it indicates that the older ages determined for the Vièville Glacier are more in line with the information from the fossil content.

Over this, an undetermined part of the profile due to its covering by ice, seems to be formed exclusively by lava beds. The next fossil occurrence corresponds to large seeds of Podocarpaceae described by Zastawniak et al. (1985) at the top of Mount Wawel, the "M ount Wawel in situ beds" (Birkenmajer, 2001). The nearly exclusive presence of Podocarpaceae remains at those younger levels provides evidence of the survival of the family in the northern A ntarctic Peninsula during the post-Early Oligocene climatic deterioration (Hunt \& Poole, 2003; Dutra, 2004; Birkenmajer et al., 2005; I vany et al., 2006).

In light of the investigations undertaken in 2006-2007, together with previous data from the literature, a tentative correlation with the fossil floras of K GI was proposed (Figure 7). Foremost to making this correlation was (i) the identification of similar processes and fossil assemblages from other Paleogene deposits in the J ames R oss B asin (Elliot, 1988; A skin, 1990; Cantrill \& Poole, 2005), (ii) marker horizons such as those characterized by fossil woods included in lavas and/or agglomerates, that coincides with the upper limit of the most diversified fossil plant successions and preceding those with poorer or no plant assemblages preserved, (iii) the relationship between the main plant beds and the superimposed conglomerate deposits (diamictites/tillites?) registered in some places of the island (e.g. upper part of Rocky B ay succession and Point Thomas). In A dmiralty B ay, those deposits were proposed to be linked to an alpine kind of ice covering and with the first evidence of a fall in temperatures, coincident with upper Middle Eocene (Birkenmajer et al., 2005). Similar climate-sensitive deposits and the gradual drop in biotic diversity coincide with the middle part of $L$ a M eseta A lloformation on Seymour Island (G andolfo et al., 1998; Ivany et al., 2008).

\section{MATERIAL AND METHODS}

Twenty-four samples containing 50 leaf impression fossils originating from imbricate leaf shoots are discussed here. A dditional forms with the same morphology will be the focus of future work. The samples studied here originate from the fossiliferous plant beds of Fossil Hill (Fildes Peninsula) and are designated by the acronym A NTF M F, and in situ/ex situ material found on the slopes of Mount Wawel and Szafer (A dmiral ty Bay) with the acronym ANTF M W and A NTF SZ, respectively. A ssociated lithologies and charcolified compressions confirm the presence of proximal and active volcanism. With regard to the upper levels of M ount Wawel slopes, as determined by the presence of surge deposits, these volcanic processes had a direct influence on fossil preservation and greatly reduced the chance of leaf cuticle preservation (Pereira et al., 2003). Otherwise, foliage remains are generally preserved as impressions within thin intercalations of reworked volcanoclastic grains deposited in shallow lakes and deltas (B irkenmajer, 2001; Poole et al., 2001; Dutra, 2001, 2004; Figure 4). 


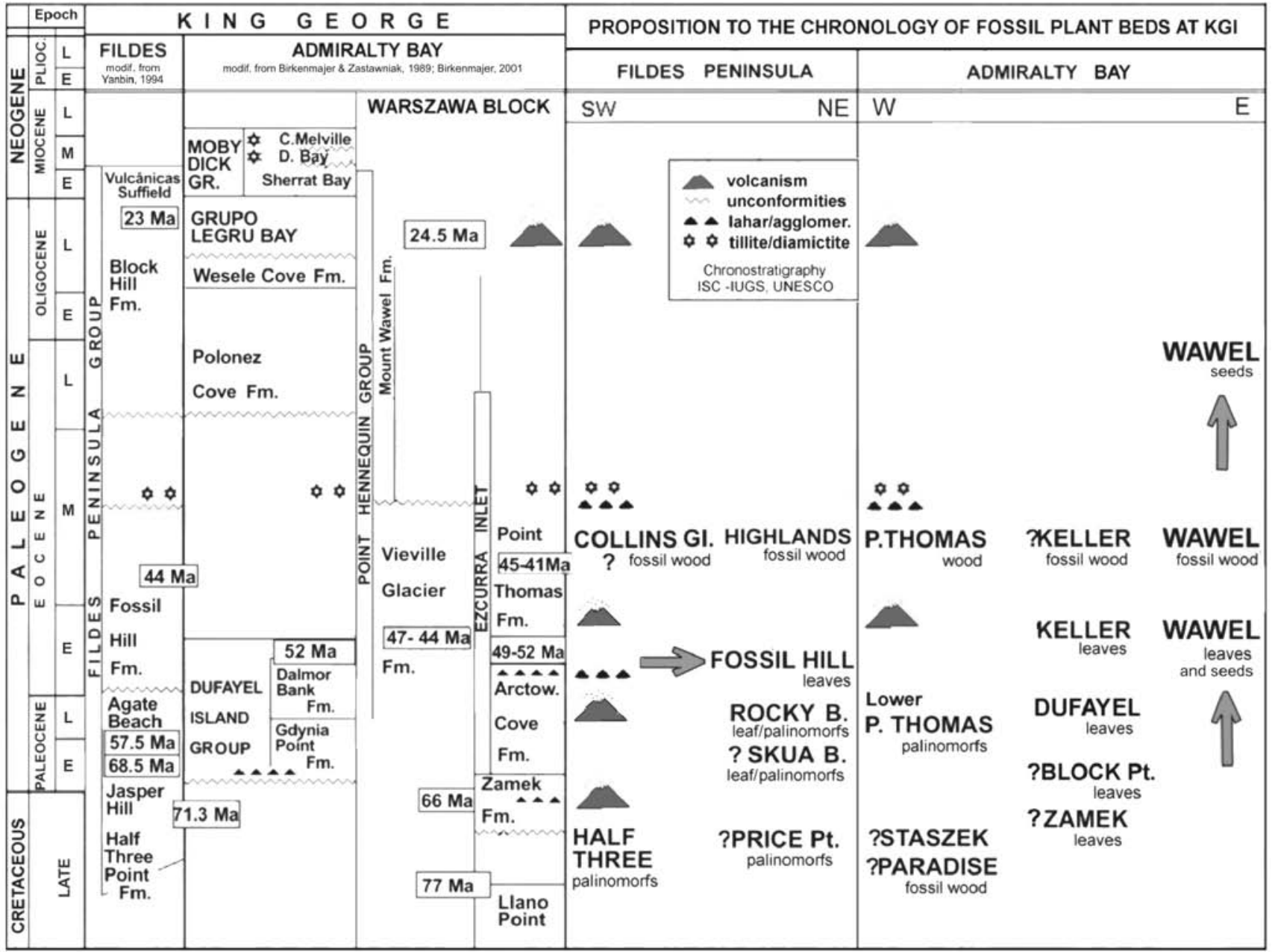

Figure 7. Proposed age and relative position of the plant fossils assemblages from the south (Fildes Peninsula) and central parts (Admiralty Bay) of King George Island (modified from Dutra, 2004). The arrows indicate where plant assemblages were found along with reproductive structures of Podocarpaceae. Radiometric ages from Birkenmajer et al. (1986), Soliani Jr. et al. (1988) and Yinxi \& Yanbin (1994). Tectonically and volcanic induced deposits follow those proposed by Birkenmajer (2001). Glacial influenced lithologies (tilittes) based on Santos et al. (1994) and Birkenmajer et al. (2005).

The plants were studied using an Olympus Stereomicroscope with photographic and drawing devices. I mages obtained were processed using Corel Draw 13. Other records of macrostructures were made with a Canon digital camera (10.2 $\mathrm{M} \mathrm{px}$ resolution) and the measurements were taken with a precision device. SEM analysis and cuticle preparations were carried out but provided no additional data.

Plant remains were compared with published descriptions of modern analogs and herbarium sheets housed at U niversidade do Vale do Rio do Sinos (UNISINOS) in the Herbarium of the Instituto A nchietano de Pesquisas (IAC) and at the Paleontological M useum (comparative collection) of the PostGraduation Program in G eology (N IT G eo). The nomenclature used in the description of shoot and leaf morphology was that suggested by de Laubenfels (1969), Offler (1984) and Wells \& Hill (1989). Comparisons with fossil material were made with published works focusing on similar fossils from the austral basins and Antarctic Peninsula. The samples described here are housed at the Paleontological M useum (sect. A ntarctica) at UNISINOS, in São Leopoldo city, Rio Grande do Sul State, B razil.
SY STEMATIC DESCRIPTIONS

Division CONIFEROPHYTA

Class GY M N OSPERM OPSIDA OrderCONIFERALES

Family PODOCA R PA CEA E Endlicher, 1847

Dacrydium vel Halocarpus

(Figures 8A-D)

1981 D acrydium vel D acrycarpus Zastawniak; p. 101-102, pl. 2, fig. 3.

M aterial. Impressions and charcolified compressions of 43 fragments, one referring to a more complete apical branch (A NTF M W-023) and the others to parts of the shoots (A NTF M W-004a to 004j, ANTF M W-019a to 019f, A NTF M W-055a to 055c, A NTF M W-060, A NTF M W-064a, A NTF M W-080a to 080c, A NTF M W-091, A NTF M W-133A a and Ba, 133Ab and $B b, 133 A C$ and $B C, 133 A d$ and $B d, A N T F M W-008$, ANTF M W-031, ANTF M W-010, ANTF M W-025A, ANTF 
M W-006, A NTF M W-009a to 009d, A NTF M W-020a, ANTF MW-001, ANTF SZ-006).

H olotype. A NTF M W-023, level C (Figure 4).

L ocality. Middle part of M ount Wawel succession, at A dmiralty Bay, K GI.

Stratigraphic unit. The levels were assigned to the Point Hennequin Group of Hawkes (1961). The plant remains, first described from moraine deposits (Wanda Glacier and "Smok Hill plant beds") and from Szafer, are now attributed to volcanoclastic and volcanic beds located at $\sim 90 \mathrm{~m}$ above sea level (Figure 4).

Age. Early Eocene.

Description. A pical shoot and isolated parts of helically to sub-opposite arranged leaf twigs, with planar insertion (angles of 45 ) , 1-2 mm wide, with mostly broad, imbricate scale-like leaves, giving way along the shoots and in some branchlets to a more linear shaped, falcate, slightly spreading and incurved ones. B ifacial leaves 1-2 mm in length and 0.5$1 \mathrm{~mm}$ wide, ranging from (short) diamond-shape types to more el ongate and unguiform, with free and blunt apices and adnate bases narrow. A baxial keels or midvein absent.

Discussion. The form and general morphology of these shoots with leaves varying in form and imbrications along the shoot are both very similar to those from the ex-situ material from the "Dragon Glacier plant beds" commented on and figured by Zastawniak (1981), and assigned without a formal description to $D$ acrydium vel D acrycarpus. These are supplemented by additional specimens and associated with its original stratigraphic level. Other morphotypes of Dacrydium (e.g. D. araucarioides) from the Mount Wawel beds have also been suggested by Zastawniak (1981).

Following the works of Quinn \& Gadek (1981) and Quinn (1982), regarding the relationships within Dacrydium s.l. and the erection of Dacrydium sect. $B$ and $C$, the taxonomic placement of these fossils, and those described by Zastawniak (1981), can be refined. Considering the records mentioned, the combination of a foliage morphology characterized by diamond-shaped imbricate leaves, with distinct forms and arrangements, which give way to more el ongated, spreading and incurved ones at the shoot apices, confirm the relation to the genus $D$ acrycarpus but a more proximal affinity with Halocarpus, rather than Dacrydium vel Dacrycarpus, as suggested by Zastawniak (1981).

Within modern species of Halocarpus, this foliage type can be found in $\mathrm{H}$. bidwillii, where the development of the typical keel that characterizes the other species of the genus is also not common. A ccording to Quinn \& Gadek (1981) and Quinn (1982), the slender and planar disposed shoots, with spirally to sub-opposite scale-like and heterophyllic leaf shoots characterize members of Dacrydium section C, which includes Halocarpus (especially H . bidwilli Quinn, formerly Dacrydium bidwilli). Today, mature foliage of $\mathrm{H}$ alocarpus and $D$ acrydium differs only by the more abrupt change from one leaf type to the other. This occurs without transition in Halocarpus (Eckenwalder, 2009).

The absence of anatomic features and the current global deficit in macrofossils attributable to $\mathrm{H}$ al ocarpus (rather than to "Dacrydium sp."), prevents certain placement within one of these two modern genera. In light of recent phylogenetic work, it is therefore timely for a revision of the austral podocarpaceous plant fossil record (see Pole, 1997) to determine whether closer taxonomic relationships can be made between fossil and extant taxa.

Further support for the presence of Halocarpus in the fossil record of K GI comes from an isolated and incomplete seed (see discussion below) found in associated levels at M ount Wawel (Figure 8G), which shows evidence of a striated epimatium similar to that found in extant forms of the genus. However, one isolated pollen cone with size and morphology very similar to those found in Dacrydium cupressinum Solander ex G. Forst., 1786 is also present (Figures 8E,F). These reproductive structures are useful in providing evidence for the presence of the Podocarpaceae at M ount Wawel, rather than Cupressaceae which can have a similar leaf shootmorphology. Reproductive structures that could belong to the Cupressaceae are as yet unknown from this locality, although cupressaceous foliage forms an important contribution to the conifer component in the Fossil Hill assemblage, in Fildes Peninsula (Zhiyan \& Haomin, 1994).

Within the pollen assemblage of Fossil Hill, at Fildes Peninsula, Dacrydium related forms are also present with the pollen grains of Trisaccites and Dacrydiumites florinii, most closely associated with modern $D$. cupressinum (Torres \& M éon, 1990; Cao, 1992; Dutra \& B atten, 2000).

On Snow Hill Island (eastern A ntarctic Peninsula), fossil forms described from the U pper C retaceous, such as Sequoia fastigiata (Sternberg) Nathorst (Halle, 1913), also share morphological characteristics with the extant species Dacrydium colensoi Hook. and D. intermedium K irk. In L ate Cenozoic beds of both southern Victoria $L$ and and erratic blocks of M cM urdo Sound, East A ntarctica, Dacrydium remains are often found associated with N othofagus (Francis etal., 2008).

In South A merica, pollen grains of $D$ acrydiumites florinii are represented in beds spanning the U pper Cretaceous to $M$ iocene, associated with macrofossils of D acrydium (Fasola, 1969; Romero, 1986; Troncoso \& Romero, 1993). Dacrydiumites becomes increasingly frequent within $\mathrm{N}$ eogene strata of those areas that formerly made up East Gondwana. However, detailed taxonomic abundances at the genus level need to be reconsidered in light of advances in podocarp systematics. In N ew Zealand and across eastern and southeastern A ustralia, including Tasmania, the macroflora and palynological assemblages indicate that Dacrydium, Dacrydium/Podocarpus, Dacrydium group B, and Parvisaccites catastus Stover \& Partridge, a type thought to be related to extant $\mathrm{H}$ alocarpus (ex Dacrydium) bidwillii/ kirkii and $D$. biforme, have been present throughout much of the Cenozoic (Pocknall, 1981; M acphail et al., 1994; Hill \& Christophel, 2001).

Halocarpus bidwillii is today a dwarf frost-resistant Podocarpaceae, exclusive to $\mathrm{New}$ Zealand, where it occurs from Cape Colville on the Coromandel Peninsula, to Stewart Island, and between 600-1,500 m in elevation in the north, but at lower altitudes nearer to sea level in the south. It is hardy, growing in both bogs and dry stony ground, usually in montane to subalpine scrub (Eckenwal der, 2009). In the west coast of the South Island, $\mathrm{H}$. bidwillii grows in mixed temperate rainforest under a canopy dominated by 

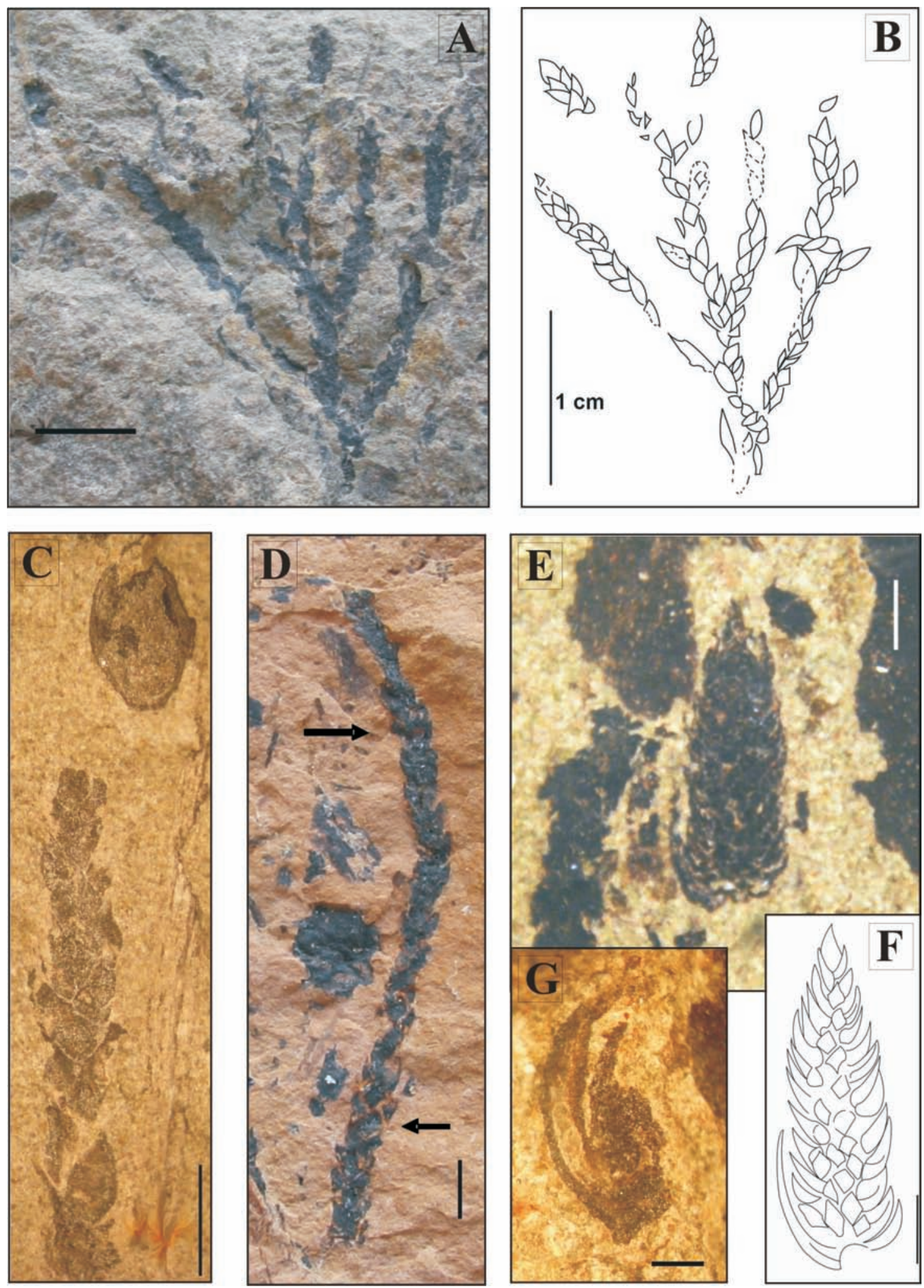

Figure 8. A-D, Apical leaf shoots of Dacrydium vel Halocarpus from Mount Wawel: A, bifacial flattened shoots, with planar and alternate insertion and spiral to sub-opposite arranged imbricate leaves (sample ANTF MW-023, scale bar= $10 \mathrm{~mm}$ ); $\mathbf{B}$, drawing in camera lucida from A to show detail; $\mathbf{C}$, detail of an apical branchlets exhibiting adpressed, diamond-shaped leaves (from level $\mathbf{C}$ of the Mount Wawel profile). The flat and isolated seed at upper right exhibits a morphology similar to that found in $H$. bidwilli and $D$. cupressinum, and the broken part could suggest predation by insects (ANTF MW-063, scale bar $=2 \mathrm{~mm}$ ); $\mathbf{D}$, detail of an apical branch showing the distinct sizes and form of leaves (arrows) in basal and upper part of the shoot (ANTF MW-010, scale bar= $2 \mathrm{~mm}$ ); $\mathbf{E}-\mathbf{F}$, isolated small pollen cone, similar to those of extant $D$. cupressinum (scale bar $=2 \mathrm{~mm}$ ); $\mathbf{G}$, ovalate and flattened seed with size similar to those of extant Halocarpus bidwilli and Dacrycarpus dacrydioides. In modern $D$. dacridioides, similar breakage features are observed following drying of the seed (ANTF MW063, scale bar $=0.5 \mathrm{~mm}$ ). 
Dacrydium cupressinum (the rimu), the same taxa inferred by the isolated cone in associated beds on K GI. The composition and diversity of this modern biome, comprising N othofagus, diversified Podocarpaceae and ferns, is in part very similar to that preserved in the Mount Wawel paleoassemblage. The difference between the modern flora and the assemblage of M ount Wawel flora is the presence of Araucaria remains, along with other angiosperm exhibiting affinities to the nowadays South A merican region (B oardman \& Dutra, 2005), which confers a mixed character to the taphoflora.

\section{Genus D acrycarpus (Endl.) C.J . Quinn, 1982 Dacrycarpus tertiarius n.comb.} (Figures 9A-D)

1928 F itzroya tertiaria B erry; p. 13, pl. 2, figs. 2-4. 1938 F itzroya tertiaria Berry; p. 60, pl. 12, fig. 2. 1940 Podocarpus tertiarius (B erry) Florin; p. 39. 1981 D acrycarpus dacrydiodes (Zastawniak, pl. 2, figs. 1-3). 1994a Podocarpus tertiarius (B erry) Florin, 1940; Zhou Zhiyan \& Li Haomin, pl.1, figs. 5-8a; text-fig. 2. $1996 \mathrm{D}$ acrycarpus? tertiarius (B erry) Zastawniak (in Doktor et al.), p. 133-134, pl. 32, fig. 1.

Material. Impressions of apical and medial portions of four vegetative shoots, sometimes covered by charcolified material (A NTF 35-002,A NTF 35-001, A NTF 35-005, ANTF 35-007).

Holotype. A NTF 35-002, basal levels of the fossiliferous interval at the top of F ossil Hill.

L ocality. Fossil Hill succession, Fildes Peninsula, K GI. Stratigraphic unit. Fossil Hill Formation (Yanbin, 1994), Fildes Peninsula Group (Hawkes, 1961).

Age. ? L ate Paleocene to Early E ocene.

Description. Elongated and slender shoots with dominant planar, sometimes alternate disposition, $1 \mathrm{~mm}$ wide, branchlets inserted at angles varying from $35^{\circ}$ to $45^{\circ}$ (1-0.8 $\mathrm{mm}$ wide). $B$ ifacial and appressed scal e-like leaves, helically arranged (2 +3 to $1+2$ parastichies) and slightly spreading, with a short acute to obtuse free portion, and well-devel oped wide adnate and decurrent base. The uniform leaf sizes ( 1.5 to $2.5 \mathrm{~mm}$ in length, 0.8 to $1 \mathrm{~mm}$ wide) only varies to little more el ongated ones in the proximal part of the branches. No keels apparent.

Discussion. The disposition of the shoots coupled with heterophyllic slightly spreading bifacial and appressed leaves, with wide decurrent adnate bases dominant over the free apices (form A from Offler, 1984), include those impressions in the range of variation found in mature foliage of the modern genus Dacrycarpus.

Zhiyan \& Haoamin (1994a, pl.1, figs. 5-8a; text-fig. 2) described fossil remains with similar morphology from the same beds as those discussed here, and formally proposed a relation to Podocarpus tertiarius (B erry) Florin, which is discussed here.

This morphotype was first discovered in Chile by Florin (1940), and was identified as having closest morphological similarity to extant Pherosphera and Dacrydium. Later, Orlando (1964) and Czajkowski \& Rösler (1986) found similar morphologies in shoots preserved in equivalent beds on Fossil Hill, atK GI.
New material found during the course of this study, with foliage morphology very similar to that described and figured by Zhiyan \& Haoamin (1994a), shows branches and branchlets with planar ramifications suggesting a close similarity to members of the genus $D$ acrycarpus rather than Podocarpus (cf. de Laubenfels 1969), which have leaves normally short petiolate and bifacial flattened (Form E from Offler, 1984). Therefore, the new generic combination Dacrycarpus tertiarius is proposed here, highlighting the morphological similarity of the fossil remains with Dacrycarpus mature foliage (Figure 9A). It also shares a common morphology with the leaf shoots assigned to Dacrycarpus? tertiarius, from the La M eseta Formation on Seymour Island by Zastawniak (D oktor et al., 1996), as well as those from Southern Chile referred to as Podocarpus dacrydioides A. Rich. by Florin (1931), and with Fitzroya tertiaria and $\mathrm{P}$. tertiarius, respectively, as described by B erry $(1928,1938)$ and Florin (1940) from the L ower E ocene beds of the Chalia and Pichileufú rivers in Patagonia (R omero, 1986).

The incomplete nature of the fossils, in particular the lack of preserved cuticle, prevents further taxonomic determination. However, notew orthy is the similarity between these fossils and the mature foliage of extant $D$. dacrydioides (A. Rich.) de Laub. M oreover, the presence in the Mount Wawel beds of two seeds with morphology and size very similar to that of Dacrycarpus (Figure 9G) and a juvenile shoot of D. dacrydioides (Zastawniak, 1981, plate 2, fig. 1) heightens the evidence for the presence of $D$ acrycarpus in the A ntarctic at this time.

Dacrycarpus related forms are also present since the $M$ iddle J urassic in the pollen assemblages (Dacrycarpites spp.) of South A merica (M artínez, 2002) and in the Upper Cretaceous, together with leaf impressions and woods, in A ntarctica, N ew Zealand and A ustralia. By the end of the Paleogene, it seems to have disappeared from the southern South A merican region, more or less coeval with its disappearance from the northern A ntarctic Peninsula (Dettmann \& Jarzen, 1990; A skin, 1990).

The quantity of fossils assigned to Dacrycarpus from the Eocene to M iocene of A ustralia and from the M iocene of $\mathrm{N}$ ew Zealand make those areas the only ones to surpass in abundance those found in the Paleogene of the northern A ntarctic Peninsula (Wells \& Hill, 1989; Pole, 1998; Hill \& W hang, 2000). In A ustral ia, some M iocene forms were related to Dacrycarpus elandensis Hill \& Whang, which shares morphological similarity to the modern species $D$. imbricatus, whilst others appear more related to $D$. dacrydioides (de L aubenfels, 1988; Pole, 1992; Carpenter et al., 1994).

In Southern A ustralia, Dacrycarpus maintained its diversity until the arrival of the severe cold, dry climate that characterized the L ower Pleistocene, when the retreat of the rainforest gave way to the arrival of E ucalyptus forests ( $\mathrm{Hill}$ \& Carpenter, 1991; J ordan, 1995; Hill \& W hang, 2000).

Today D acrycarpus has a broad geographical distribution across the eastern areas of the Southern Hemisphere, in forests from South China to Fiji, N ew Guinea (where it has its greatest variety and number of species) and across to $\mathrm{New}$ Zealand. Except in the last country, where it is broadly dispersed, its distribution is restricted to the eastern sides of 

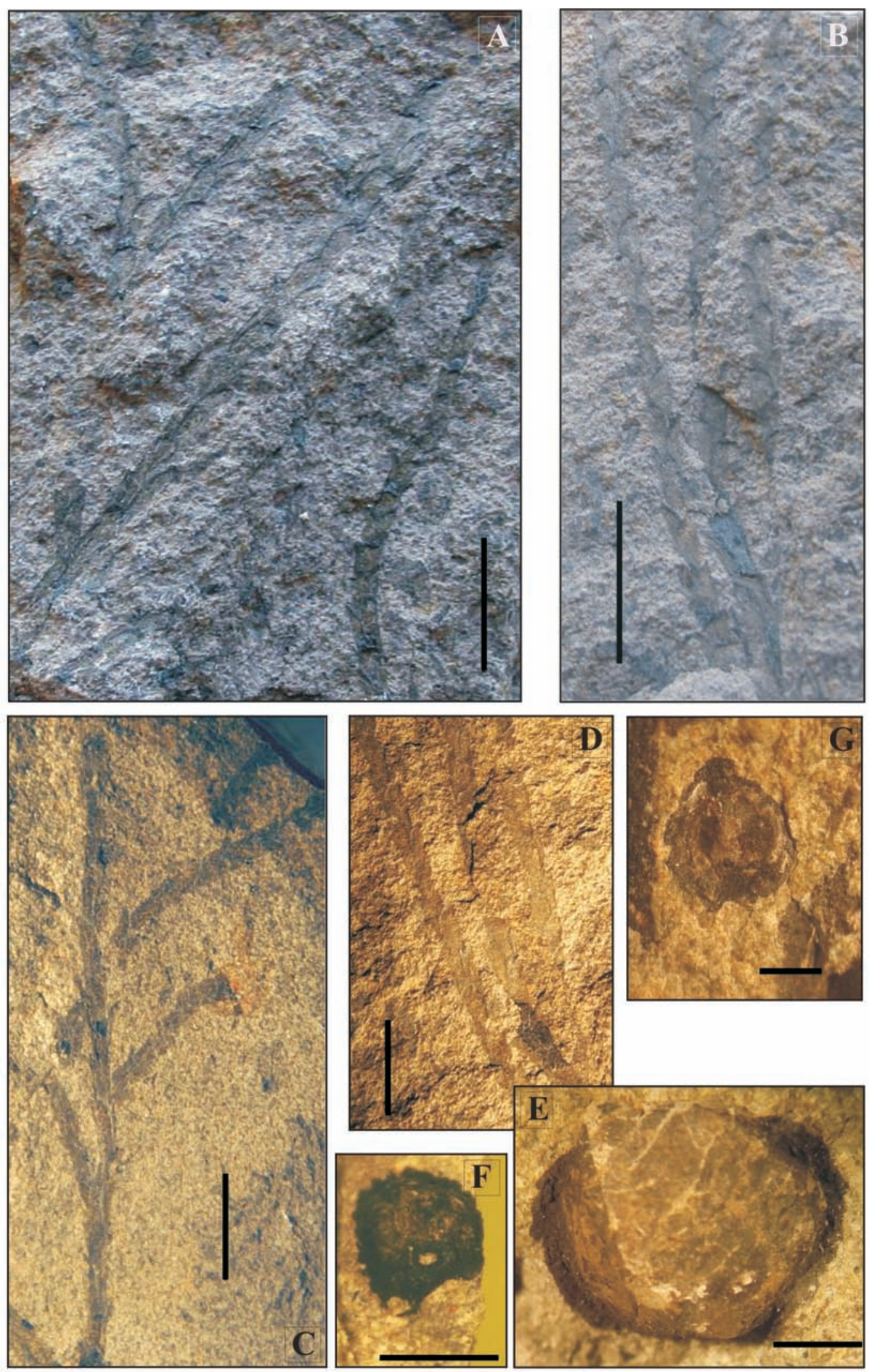

Figure 9. A-D, Apical branch and branchlets of Dacrycarpus tertiarius n.comb., originating from the upper most plant assemblage at Fossil Hill, Fildes Peninsula (Figure 2), showing the slender leaf shoots and short imbricate leaves: A-B, holotype (sample ANTF 35-002, scale bar= 10 mm); C, aspect of the foliage showing the planar and alternate insertion in slender shoots (ANTF 35-001, scale bar= $10 \mathrm{~mm}$ ); $\mathbf{D}$, detail of the spiral to sub-opposite, ovalate and imbricate leaves (ANTF 35-005, scale bar= $10 \mathrm{~mm}$ ). E-G, isolated seeds from level A of Mount Wawel: E, isolated seed (ANTF MW-014A, scale bar= $10 \mathrm{~mm}$ ) similar to Carpolites sp. 1 of Zastawniak et al. (1985); $\mathbf{F}$, round seed similar to that found in modern Dacrycarpus species and in Lepidothamnus intermedius, with wrinkled testa or epimatium (ANTF MW-016, scale bar= $2 \mathrm{~mm}$ ); $\mathbf{G}$, incomplete and detached seed, also with affinity to those found in modern Lepidothamnus genus (ANTF MW-063, scale bar= $1 \mathrm{~mm}$ ). 
the land masses where wet oceanic climates prevail. The species $D$. dacrydioides is now restricted to New Zealand, where it dominates in stature and grows on the fertile soils of flood plains and low terraces of fluvial basins (de L aubenfels, 1988; Blanchon, 2005). D. dacrydioides can al so grow up to an al titude of $600 \mathrm{~m}$, where it adopts a shrub habit, especially on South Island, New Zealand (Cubitt \& M olloy, 1994). In south Westland, it contributes to the lowland forest that characteristically comprises Dacrydium cupressinum, Prumnopytis ferruginea and Weinmannia racemosa, colonizing mineral-rich and silty soils resulting from intense flood disturbance (Duncan, 1993).

\section{SEEDS}

A diversity of dispersed seeds related to the Podocarpaceae has previously been found in the in-situ "M ount Wawel beds" by Zastawniak et al. (1985). They assigned these seeds to Carpolites spp., and related them to Podocarpus sect. Stachycarpus. Similar forms also occur in extant members of the genera $\mathrm{F}$ alcatifolium, Acmopile and Prumnopytis (Eckenwalder, 2009). In the studied material described here, other distinct seeds were found and between them, only one exhibits a size (5 $\mathrm{mm}$ long) similar to that described by those authors (Figure $9 \mathrm{E}$ ).

The other seeds here originate from the basal-most levels (L evel A, Figure 4) and include two main morphotypes. They are either rounded or flattened, and some have parts of the epimatium preserved, which suggests morphological similarity to D acrycarpus and D acrydium (Eckenwalder, 2009). M odern podocarp seeds show a strong degree of similarity, and therefore, it is not always possible to pinpoint their affinities, but the small seeds identified here can be subdivided further based on morphological characters. Those flattened and with an apparently resistant testa, complete with Iongitudinal striations, is common to modern Dacrydium and its segregated genera, such as Manoao, Halocarpus (e.g. $\mathrm{H}$. bidwilli) or Lagarostrobus (Figure $8 C, G$ ). Interestingly, the kind of fragmentation exhibited in one of them (Figure $8 \mathrm{C}$ ) suggests possible evidence for plant-insect interaction. Similar features can be seen in modern detached seeds of $D$. cupressinum following germination. The type of fragmentation, with characteristic jagged edges, could attest to the action of weta insects (Family Stenopelmatidae), as they break the seed coats (B everidge, 1964).

The second morphotype, with more rounded appearance, apical protuberances and sometimes with a low crest, is more suggestive of Dacrycarpus (e.g. D. dacrydioides), Prumnopytis or Lepidothamnus (Figures $9 F, G$ ).

The presence of these reproductive structures serves to strengthen evidence for the presence of the family Podocarpaceae at K GI during the Paleogene, supported also by previous works. The associated depositional features (ichnofossils, mud cracks and rain drops) provide information regarding their probable transport from high areas, prior to deposition in ephemeral and shallow lakes.

\section{FINAL COMMENTS}

The shoots covered by short, imbricate and bifacial leaf types and the seeds found in the Paleogene strata of $\mathrm{KGI}$ provide good evidence for the presence of podocarps growing across the hilly slopes and in lowland coastal areas, during periods of quiescence, or at a time preceding volcanic activity. The fragmentary and disconnected nature of the plant remains, dominated by parts of apical shoots also indicates a parauthoctonous (e.g. Fossil Hill) and allochthonous (in middle to upper M ount Wawel fossiliferous intervals) nature of deposition, respectively, through either transportation in ephemeral rivers and deltas or from surge processes that coincided with the beginning of a new period of volcanic activity (e.g. level C, from M ount Wawel deposition).

Otherwise, the assemblage at F ossil Hill, due to its greater abundance in Podocarpus spp. and other needle-leaf shoots, ferns and broader and bigger $(\sim 12 \mathrm{~cm}$ long) leaves of Nothofagus seems to reflect an environmental context distinct from that of probably coetaneous M ount Wawel basal levels. Here, the imbricate leaf types related to Dacrydium s.l. are more diverse and abundant and are accompanied by Araucaria representatives, Dicksoniaceae ferns and numerous Nothofagus, which have smaller leaf sizes. This would suggest that at least one assemblage originated from slopes or higher areas, subject to a little colder or drier conditions, which is supported by the paleoclimatic data derived from wood and leaf analyses. The values obtained at the end of the Paleocene and L ower Eocene for K GI in fossil wood ring and leaf margin analyses, indicates a mean annual temperature (MAT) in the range of about $12^{\circ} \mathrm{C}$ or $13^{\circ} \mathrm{C}$, respectively for the M ount Wawel and Fossil Hill localities, similar to the values obtained from the Early E ocene levels from J ames R oss and Seymour Islands, where the M AT is thought to have been about $13.5^{\circ} \mathrm{C}$ (Poole et al., 2005). Yet, with regard to mean annual precipitation (MAP), the Mount Wawel floras appear to have experienced drier conditions $(\sim 950 \mathrm{~mm})$, while the Fossil Hill locality seems to have been much wetter ( 1730 $\mathrm{mm}$ ). A t this moment, Seymour I sland, located on the eastern side of the A ntarctic Peninsula, appears to have experienced precipitation levels similar to those observed today in south $B$ razil and the Valdivian region in Chile (i.e. $\sim 2311 \mathrm{~mm}$ ). It suggests that probably the westerly system of winds that now have a great influence over the humidity in the area, had not yet established or had little influence during the end of the Pal eocene and early E ocene times.

The more continuous succession from Mount Wawel (levels $A$ to D) and the upward impoverishment of flora and the reduction in leaf sizes (e.g. Nothofagus related forms), support the proposition of an initial drastic drop in regional temperatures dating back to the beginning of $\mathrm{M}$ iddle Eocene (B irkenmajer et al., 2005; I vany et al., 2008). Today, the modern podocarp relatives whose remains have been found at these upper levels exist in wet, cold habitats over mountains and/ or near sea in higher latitudes. This confirms the podocarps' resistance to cold climate which characterized A ntarctica after post-M iddle E ocene times, documented by the in-situ seeds found on the top of M ont Wawel.

Taking into account the structural complexity of the lithologies at K GI, these podocarp-rich marker horizons are useful for the establishment of the stratigraphic framework across the K GI. M oreover, it may also be possible to use the most diversified planthorizons (in F ossil Hill and middle alti- 
tude of Mount Wawel) and the floristic nature of the assemblages to synchronize deposits on K GI with those in the upper part of the Cross Valley Formation, or with the lower part of $L$ a M eseta Formation on Seymour Island, which suggests a time between the end of the Paleocene (Fossil $\mathrm{Hill}$ ) through the beginning of the Middle Eocene (M ount Wawel succession). In the last place, it expresses a discrepancy with the stratigraphic model proposed by Birkenmajer (2001), which could be attributed to the ex-situ nature of the fossil assemblages at the time of his works, and/or to the alleged complex structural character of the island.

The imbricate-leaved podocarps discussed here show morphologies very similar to those of extant $\mathrm{D}$ acrydium (or Halocarpus) and Dacrycarpus, found today on oceanic islands across the eastern flank of the Southern Hemisphere, especially South and Stewart Islands (New Zealand). Therefore mainly the modern biomes in the last islands (located at higher latitudes and where both taxa occur) may prove to be a good living analogue for the ecological context, as well as providing a more detailed understanding of the climatic conditions that presided over King George Island between the end of Paleocene and lower part of the Eocene. The association of these podocarps with other plant remains, some of them with clear affinity to taxa now living in South A merica, can also contribute to our understanding of the importance of coastal environments around Antarctica for the origin and/or distribution of the modern vegetation in the Southern Hemisphere.

\section{ACKNOWLEDGMENTS}

We would like to thank the U niversidade do Vale do Rio do Sinos (UNISINOS) and its Post-Graduation Program in Geology for financial and technical support, through CA PES by way of a M aster's Grant to DF. For financial support and facilities in the field, we are grateful to CN Pq/PROA NTAR and SECIR M , respectively. We also thank M. Pole, I. Poole and the external reviewers for the comments, suggestions and advice they offered during the course of this work.

\section{REFERENCES}

A nderson, J.M .; A nderson, H.M . \& Cleal, C.J . 2007. B rief H istory of the Gymnosperms: Classification, Biodiversity, Phytogeography and E cology. Pretoria, SA NBI, 280 p.

A skin, R.A. 1990. Campanian to Paleocene spore and pollen assemblages of Seymour Island, A ntarctica. Review of Paleobotany and Palynology, 65:105-113.

Axsmith, B.J.; Taylor, T.N. \& Taylor, E.L. 1998. A natomically preserved leaves of the conifers Notophytum krauselii (Podocarpaceae) from the Triassic of A ntarctica. American J ournal of Botany, 85(5):704-713.

Barton, C.M. 1965. The geology of South Shetland Islands. III. The stratigraphy of K ing George Island. Scientific Reports of the British Antarctic Survey, 44:1-33.

B erry, E. 1928. Tertiary fossil plants from the A rgentine R epublic. U nited States National M useum Proceedings, 22(73):1-27.

B erry, E.W. 1938. Tertiary flora from the Rio Pichileufú, A rgentina. Special Papers of the Geological Society of America, 12:1140.

B everidge, A.E. 1964. Dispersal and destruction of seed in central
N orth I sland podocarp forests. P roceedings of the N ew Zealand Ecological Society, 11:48-55.

Birkenmajer, K. 2001. M esozoic and Cenozoic stratigraphic units in parts of the South Shetland I slands and Northern A ntarctic Peninsula (as used by the Polish A ntarctic Programmes). Studia Geologica Polonica, 118:5-188.

Birkenmajer, K.; Delitala, M.C.; Narebski, W.; Nicoletti, M. \& Petrucciani, C. 1986. Geochronology of Tertiary island-arc volcanics and glacigenic deposits, King George Island South Shetland Islands (West A ntarctica). Bulletin of the Polish A cademy of Sciences, Earth Sciences, 3(34):257-273.

Birkenmajer, K.; Gazdzicki, A.; K rajewski, K.P.; Przybycin, A.; Solecki, A.; Tatur, A \& \& Yoon. 2005. First Cenozoic glaciers in West A ntarctica. Polish Polar Research, 26(1):3-12.

Birkenmajer, K . \& Zastawniak, E. 1989. Late Cretaceous-E arly Tertiary floras of King George Island, West A ntarctic: their stratigraphic distribution and palaeoclimatic significance. In: J .A . Crame (ed.) Origins and Ev volution of the Antarctic Biota, The Geological Society, Special Publication, v. 47, p. 227-240.

Blanchon, D. 2005. Plant Diversity. In: S. PA RSON S (ed.) Biology aotearoa: unique flora, fauna $\&$ fungi, Pearson Benjamin Cummings, p. 32-41.

Boardman, D. \& Dutra, T.D. 2005. U pper Paleocene?-Lower E ocene fossils rel ated to A raucariaceae from $\mathrm{K}$ ing George Island, A ntarctic Peninsula. In: INTERNATIONAL PALEOBOTANICAL CONFERENCE, 7, 2005. Abstracts, Bariloche, p. 86.

Brodribb, T.J. \& Hill, R.S. 2003. Implications for leaf and shoot physiology in Podocarpaceae. Acta Horticulturae, 615:173-174.

Cantrill, D.\& Poole, I. 2005. Taxonomic turnover and abundance in Cretaceous to Tertiary wood floras of A ntarctica: implications for changes in forest ecology. Palaeogeography, Palaeoclimatology, Palaeoecology, 215:205-219.

Cao, L. 1992. L ate Cretaceous and E ocene palynofloras from Fildes peninsula, King George Island (South Shetland Island), A ntarctica. In: Y. Y oshida, K. K aminuma \& K. Shiraischi (eds.) Recent Progress in Antarctic Earth Science, Terra Scientific Publishing, p. 363-369.

Carpenter, R. J.; Hill, R. \& J ordan, G. J . 1994. Cenozoic vegetation in Tasmania. In: Hill, R. (ed.) History of the Australian Vegetation: Cretaceous to Recent, Cambridge University Press, p. 276-298.

Chaw, S.M .; Parkinson, C.L.; Cheng, Y.; Vincent, T.M . \& Palmer, J.D. 2000. Seed plant phylogeny inferred from all three plant genomes: monophyly of extant gymnosperms and origin of Gnetales from conifers. Proceedings of the National Academy of Sciences, 97(8):4086-4091.

Cubitt, G. \& M olloy, L. 1994. Wild New Zealand. Cambridge, The M IT Press, $208 \mathrm{p}$.

Cunha, M .B.; Dutra, T.L. \& Cardoso, N . 2008. U ma Dicksoniaceae fértil no E oceno da Il ha K ing G eorge, Península A ntártica. Gaea, 4(1):1-13.

Czajkowski, S. \& Rösler, O. 1986. Plantas fósseis da Península Fildes, Ilha Rei J orge (Shetlands do Sul): morfografia das impressões foliares. Anais da Academia Brasileira de Ciências, 58:99-110.

de $L$ aubenfels, D.J . 1969. A revision of the Malesian and Pacific rainforest conifers, I. Podocarpaceae (in part). J ournal of the Arnold Arboretum, 50:274-314.

de L aubenfels, D.J . 1988. Coniferales. In: C.G.G.J . van Steenis \& W.J.J.O. de Wilde (eds.) Flora Malesiana, K luwer A cademic Publishers, v. 10, p. 419-442.

Doktor, M.; Gazdzicki, A.; Jerzmanska, A .; Porebski, S.J. \& Zastawniak, E. 1996. A plant-and-fish assemblage from the Eocene La M eseta Formation of Seymour Island (A ntarctic Peninsula) and its environmental implications. Palaeontologia Polonica, 55:127-146.

Duncan, R.P. 1993. Flood disturbance and the coexistence of species 
in a lowland podocarp Forest, South Westland, New Zealand. J ournal of E cology, 81(3):403-416.

Dutra, T.L. 2001. Paleoflora da ilha 25 de M ayo, Peninsula A ntártica: contribuição à paleogeografia, pal eoclima e para a evolução de Nothofagus. Asociación Paleontológica Argentina, Publicación E special, 8:29-37.

Dutra, T.L. 2004. Paleofloras da A ntártica e sua relação com os eventos tectônicos e paleoclimáticos nas al tas latitudes do sul. Revista Brasileira de Geociências, 3(34):401-410.

Dutra, T.L. \& B atten, D. 2000. The U pper Cretaceous flora from King George Island, an update of information and the pal eobiogeographic value. Cretaceous Research, 21(2-3):181-209.

Dutra, T.L. \& Wilberger, T.P. 2010. Epidermal structure and taphonomy of Pagiophyllum Heer in the M esozoic beds from the Paraná B asin, Rio Grande do Sul, Brazil. In: CONGRESO ARGENTINO DE PALEONTOLOGÍA Y BIOESTRATIGRAFÍA, 10/ CONGRESO LATINOAMERICANO DE PALEONTOLOGÍA, 7, 2010. Resúmenes, La Plata, M useo de La Plata, p. 159.

Eckenwalder, J.E. 2009. Conifers of the world: the complete reference. Oregon, Timber Press, $720 \mathrm{p}$.

Elliot, D. 1988. The J ames R oss B asin, northern A ntarctic Peninsula. In: CONGRESO GEOLÓGICO CHILENO, 5, 1988. Resúmenes, Santiago, Universidad do Chile, p. 226.

Fasola, A . 1969. Estúdio palinológico de L a Formacion L oreto (Terciário M édio) Província de M agallanes, Chile. Ameghiniana, 6:3-49.

Florin, C.R. 1931. Untersuchungen zur Stammesgeschichte der Coniferales und Cordaitales, I. M orphologie und Epidermisstruktur der A ssimilationsorgane bei den rezenten Koniferen. Kungliga Svenska Vetenskaps-Akademia Handlingar, 10(3):1-588.

Florin, C.R. 1940. The Tertiary fossil conifers of South Chile and their phytogeographical significance. Kungliga Svenska Vetenskaps-A kademia Handlingar, series III, 19( 2):1-107

Fontes, D. 2008. Registro fóssil de Podocarpaceae na ilha King George e a sua relação com os eventos paleoclimáticos e paleoambientais. Curso de Pós-Graduação em Geologia, U niversidade do Vale do Rio do Sinos, M. Sc. Thesis, 196 p.

Francis, J. E.; A shworth, A.; Cantrill, D.J.; Crame, J.A.; Howe, J.; Stephens, R.; Tosolini, A .M .\& Thorn, V. 2008. 100 M illion Y ears of A ntarctic Climate Evolution: Evidence from Fossil Plants. In: A .K. Cooper; P.J . B arrett; H. Stagg; B. Storey; E. Stump; W. Wise and the 10th ISA ES editorial team (eds.) Antarctica: a keystone in a changing world, National A cademies Press, p. 19-27.

Francis, J.E. \& Hill, R.S. 1996. Fossil plants from the Pliocene Sirius group, Transantarctic M ountains: evidence for climate from growth rings and fossil leaves. P alaios, 11:389-396.

Gandolfo, M .A.; M arenssi, S.A. \& Santillana, S.N. 1998. Flora y paleoclima de La Formación La M eseta (Eoceno M édio), isla M arambio (Seymour), A ntártida. Asociación Paleontológica Argentina, P ublicación Especial, 5:155-162

Halle, T.G. 1913. The Mesozoic flora of Grahan Land. Wissenschaftliche Ergebnisse der Schwedishen SüdpolarExpediton 1901-1903, 3(14):1-123.

Hawkes, D.D. 1961. The G eology of the South Shetland I slands. I. The petrology of the King George Island. Scientific Reports of the F alkdland Island Departament Survey, 26:1-28.

Herbst, R.; Troncoso, A . \& M uñoz, J . 2005. Las tafoloras triásicas de la región de los L agos, X ma Region, Chile. Ameghiniana, 42(2):377-394.

Hill, K.D. 1998. Introduction to the Gymnosperms, Coniferophyta, Cycadophyta. In: A.E. Orchard (ed.) Flora of Australia: F erns, Gymnosperms and Allied Groups, CSIRO, v. 48, p. 597-661.

Hill, R.S. \& B rodribb, T.J . 2003. Evolution of conifer foliage in the Southern Hemisphere. Acta Horticulturae, 615:53-58.

Hill, R.S. \& Carpenter, R.J. 1991. Evolution of Acmopyle and Dacrycarpus (Podocarpaceae) foliage as inferred from macrofossils in south-eastern A ustralia. Australian Systematic Botany, 4:449-79.

Hill, R.S. \& C hristophel, D.C. 2001. Two new species of D acrydium (Podocarpaceae) based on vegetative fossils from middle E ocene sediments at N elly Creek, South A ustral ia. Australian Systematic Botany, 2(14):193-205.

Hill, R.S. \& W hang, S.S. 2000. Dacrycarpus (Podocarpaceae) macrofossils from $\mathrm{M}$ iocene sediments at Elands, eastern A ustralia. Australian Systematic B otany, 13(3): 395-408.

Hunt, R.J . \& Poole, I. 2003. Paleogene West A ntarctic climate and vegetation history in light of new data from $\mathrm{K}$ ing $\mathrm{G}$ eorge Island. Geological Society of America Special Paper, 369:395-412.

Ivany, L.C.; L ohmann, K.C.; Hasiuk, F.; Blake, D.B.\& Glass, A. 2008. E ocene climate record of a high southern latitude continental shelf: Seymour I sland, A ntarctica. Geological Society of America Bulletin, 120:659-678.

I vany, L.C.; Van Simaeys, S.; Domack, E.W. \& Samson, S.D. 2006. Evidence for an earliest Oligocene ice sheet on the A ntarctic Peninsula. Geology, 34(5):377-380.

Jordan, G.J. 1995. Extinct conifers and conifer diversity in the Early Pleistocene of western A ustralia. Review of Paleobotany and Palynology, 84:375-387.

Kelch, D.G. 1998. Phylogeny of Podocarpaceae: comparison of evidence from morphology and 18S RDN A. American J ournal of Botany, 85(7):986-996.

Li, J. \& Zhen, S. 1994. New materials of bird ichnites from Fildes Peninsula, K ing George Island, A ntarctica. In: S. Yanbin (ed.) Stratigraphy and Palaeontology of F ildes P eninsula, King G eorge Island, Antarctica, B eijing Science Press, v. 3, p. 246-258.

Li, Z.N.; Liu, X.; Zheng, X.; Jin, Q. \& Li, G. 1989. Tertiary volcanism and formation of volcanic rocks in the Fildes Peninsula, King George Island, A ntartic. In: INTERNATIONAL SYMPOSIUM ON ANTARCTIC RESEARCH, 1, 1989. Proceedings, Hangzhou, p. 114-118.

M acphail, M.K.; Alley, N .F.; Truswell, E.M . \& Sluiter, I.R.K. 1994. Early Tertiary vegetation: evidence from spores and pollen. In: R.S. Hill (ed.) H istory of the Australian vegetation Cretaceous to Recent, Cambridge University Press, p. 189-261.

M eyer-B erthaud, B. \& Taylor, T.N. 1991. A probable conifer with podocarpaceous affinities from the Triassic of A ntarctica. Review of Palaeobotany and Palynology, 67:179-198.

M ill, R.R. 2003. Towards a biogeography of the Podocarpaceae. Acta Horticulturae, 615:137-147.

Molloy, B.P.J. 1995. Manoao (Podocarpaceae), a new monotypic conifer genus endemic to $\mathrm{N}$ ew Zealand. New Zealand J ournal of Botany, 33:183-201.

Offler, C.E. 1984. Extant and fossil coniferales of A ustralia and New Guinea. Part 1. A study of external morphology of the vegetative shoots of the extant species. Palaeontographica B, 93:1-34.

O rlando, H.A . 1964. The F ossil Flora of the sorroundings of A rdley Peninsula (Ardley Island), 25 de $M$ ayo Island (K ing George Island), South Shetland Islands. In: R.J. A die (ed.) Antarctic Geology, North Holland Publischer, p. 629-636.

Page, C.N. 1999. Podocarpaceae. In: W.S. Judd; C.S. Campbell; E.A. Kellog \& P.F. Stevens (eds.) Plant Systematics - a phylogenetic approach, A ssociates Inc. Publishers, p. 332-346.

Pankhurst, R.J . \& Smellie, J. 1983. K-A r geochronology of the South Shetland Islands, L esser A ntarctica: apparent lateral migration of J urassic to Q uaternary island arc volcanism. E arth and Planetary Science Letters, 66:214-222.

Patel, R.N. 1967. Wood anatomy of Podocarpaceae indigenous to N ew Zealand. 1. Dacrydium. New Zealand J ournal of Botany, 5:171-184.

Pearson, P.N .; Ditchfield, P.W.; Singano, J .; Harcourt-Brown, K.G.; Nicholas, C.J .; Olsson, R.K.; Shackleton, N.J \& \& Hall, M.A. 
2001. Warm tropical sea surface temperatures in the Late Cretaceous and Eocene epochs. Nature, 413:481-487.

Pereira, F.; D utra, T.L . \& A Imeida, D .P.M . 2003. A mbientes vul cânicos associados à paleoflora no Cretáceo e Terciário da Ilha Rei George, A ntártica. In: L.R. Ronchi \& F.J. Althoff (orgs.), Caracterização e modelamento de depósitos minerais, Editora Unisinos, p. 387-410.

Philippi, R.A. 1861. Zwei neue Gattungen der Taxineen aus Chile. Linnaea, 30:730-735.

Pocknall, D.T. 1981. Pollen morphology of the New Zealand species of Dacrydium Solander, Podocarpus L'Heritier, and D acrycarpus Endlicher (Podocarpaceae). N ew Zealand J ournal of Botany, 19:67-95.

Pole, M.S. 1992. Eocene vegetation from Hasties north-eastern Tasmania. Australian Systematic Botany, 5:431-475.

Pole, M.S. 1997. M iocene conifers from the Manuherikia Group, New Zealand. J ournal of the Royal Society of New Zealand, 27(3):355-370.

Pole, M.S. 1998. Paleocene gymnosperms from M ount Somers, New Zealand. J ournal of the Royal Society of New Zealand, 28:375-403.

Pole, M.S. 2001. Can long-distance dispersal be inferred from the N ew Zealand plant fossil record? Australian J ournal of Botany, 49(3):357-366.

Poole, I.; Cantrill, D.J. \& U tescherd, T. 2005. A multi-proxy approach to determine A ntarctic terrestrial palaeoclimate during the $L$ ate $C$ retaceous and Early Tertiary. Palaeogeography, Palaeoclimatology, Palaeoecology, 222:95-121.

Poole, I.; H unt, R.J . \& Cantrill, D.J . 2001. A fossil wood flora from K ing George Island: ecological implications for an A ntarctic Eocene vegetation. Annals of Botany, 88:33-54.

Quinn, C.J. 1982. Taxonomy of Dacrydium Sol. ex Lamb. emend. de Laub. (Podocarpaceae). Australian J ournal of Botany, 30:311-320.

Quinn, C.J . \& Gadek, P. 1981. B iflavones in Dacrydium sensu lato. Phytochemistry, 20:677-681.

Quinn, C.J. \& Price, R.A. 2003. Phylogeny of the southern hemisphere conifers. Acta H orticulturae, 615:129-136.

Romero, E.J . 1986. Pal eogene phytogeography and climatology of South A merica. Annals of the M issouri Botanical Garden, 73:449-461.

Romero, E.J . \& A rguijo, M.H. 1981. A nálisis bioestratigráfico de las tafofloras del Cretácico Superior de A ustrosudamerica. In: E.J . Romero e M .H. A rguijo (eds.) C uencas sedimentarias del J urásico y Cretácico deA mérica del Sur, Comité Sudamericano del J urásico y Cretácico, v. 2, p. 393-406.

Rösler, O.; Santos, P.R.; Rocha-Campos, A.C.; Trompette, R.R.; Uhlein, A.; Gipp, M.\& Simões, J.C. 1994. Review of Tertiary glaciation in King George Island West A ntartica: preliminary results. Pesquisa Antártica Brasileira, 2:87-99.

Shanzen, Z. \& Qingzhi, W. 1994. Palaeocene petrified wood on the west side of Collins glacier in the K ing George Island, A ntarctica. In: S. Y anbin (ed.) Stratigraphy and Palaeontology of Fildes Peninsula, King G eorge Island, Antarctica, B eijing SciencePress, v. 3, p. 231-238.

Shellito, C.J .; Sloan, L.C. \& Huber, M. 2003. Climate model sensitivity to atmospheric $\mathrm{CO} 2$ levels in the early-middle Paleogene. Palaeogeography, Palaeoclimatology, Palaeoecology, 93:113-123.

Smellie, J.L.; Pankhurst, R.J .; Thomson, M .R.A \& \& Davies, R.E.S. 1984. The geology of the South Shetland Islands: VI. Stratigraphy, geochemistry and evolution. Scientific Reports of the British Antarctic Survey, 87:1-85.

Soliani J r., E.; K awashita, K.; Fensterseifer, H.C.; H ansen, M .A .F. \& Troian, F.L. 1988. K -Ar ages of the Winkel Point Formation
(Fildes Peninsula Group) and associated intrusions, King George Island, South Shetland Islands, A ntarctica. Série Científica del Instituto Antártico Chileno, 38:133-139.

Stockey, R.A. 1990. Antarctic and Gondwana Conifers. In: T.N. Taylor \& E.L. Taylor (eds.) Antartic Paleobiology, its role in the reconstruction of G ondwana, Springer-Verlag, p. 179-191.

Torres, T. \& M eón, H. 1990. Estudio palinológico preliminar de Cerro Fósil, Península Fildes, I sla R ey J orge, A ntártica. Série Científica del Instituto Antártico C hileno, 40:21-39.

Townrow, J.A. 1967. On Rissikia and M ataia podocarpaceous conifers from the Lower M esozoic of Southern lands. Papers and P roceedings of the Royal Society of Tasmania, 101:103-136.

Troncoso, A . 1986. Nuevas órganos-especies en la tafoflora terciaria inferior de Peninsula Fildes, Isla Rey Jorge, A ntártica. Serie Científica del Instituto Antártico C hileno, 34:23-46.

Troncoso, A. \& Romero, E.J . 1993. Consideraciones acerca de las coníferas del M ioceno de Chile Central Occidental. Boletin del Museo de Historia Natural del Chile, 44:47-71.

Veblen, T.T.; B urns, B.R.; K itzberger, T.; Lara, A. \& Villalba, R. 1995. The ecology of the conifers of South A merica. In: N. Enright \& R. Hill (eds.), Ecology of the Southern Conifers, Smithsonian Institution Press, p. 120-155.

Wells, P.M . \& Hill, R.S. 1989. Leaf morphology of the imbricateleaved Podocarpaceae. Australian Systematic Botany, 2:369-386.

Winkworth, R.C.; Wagstaff, S.J .; G lenny, D . \& L ockhart, P.J . 2002. Plant dispersal N.E.W.S. from N ew Zealand. Trends in E cology \& Evolution, 17(1):514-520.

Yanbin, S. 1994. Subdivision and correlation of Cretaceous to Pal eogene vol cano-sedimentary sequence from Fildes Peninsula, K ing George I sland, A ntarctica. In: S. Y anbin (ed.), Stratigraphy and Palaeontology of Fildes Peninsula, King George Island, Antarctica, B eijing Science Press, v. 3, p.1-36.

Y inxi, W. \& Y anbin, S. 1994. Rb-Sr isotopic dating and trace el ement, $R E E$ geochemistry of $L$ ate $C$ retaceous vol canic rocks from $K$ ing George Island, A ntarctica. In: S. Y anbin (org.), Stratigraphy and Palaeontology of Fildes Peninsula, King George Island, Antarctica, B eijing Science Press, v. 3, p. 109-131.

Zachos, J.C.; Shackleton, N. J.; Revenaugh, J.S.; Pälike, H. \& Flower, B.P. 2001. Climate response to orbital forcing across the Oligocene-M iocene B oundary. Science, 292:274-278.

Zachos, J.C.; Wara, M.W.; Bohaty, S.; Delaney, M.L., Petrizzo, M.R.; Brill, A.; B ralower, T.J. \& Premoli-Silva, I. 2003. A transient rise in tropical sea surface temperature during the Pal eocene-E ocene Thermal M aximum. Science, 302:1551-1554.

Zastawniak, E. 1981. Tertiary leaf flora from the Point Hennequin Group of King George Island (South Shetland Island, A ntarctica), Preliminary Report. Studia Geologica Polonica, 72:97-108.

Zastawniak, E.; Wrona, R.; Gazdzicki, A . \& Birkenmajer, K. 1985. Plant remains from the top part of the Point Hennequin Group (U pper Oligocene), K ing G eorge Island (South Shetland I slands, A ntarctica). Studia G eologica P olonica, 81:143-164.

Zavattieri, A.M. 1990. Palynology of the Las Cabras Formation (Triassic) in its type locality, Cuyo B asin (M endoza, A rgentina). Part I. Triletes spores. Ameghiniana, 27(1-2):107-129.

Zhiyan, Z. \& Haomin, L. 1994a. Early Tertiary gymnosperms from Fildes Peninsula, K ing George Island, A ntarctica. In: S. Y anbin (ed.) Stratigraphy and $\mathrm{P}$ alaeontology of F ildes P eninsula, King George Island, A ntarctica, B eijing Science Press, v. 3, p. 208-230.

Zhiyan, Z. \& Haomin, L. 1994b. Some L ate Cretaceous plants from King George Island, A ntarctica. In: S. Y anbin (ed.) Stratigraphy and Palaeontology of Fildes Peninsula, King George Island, Antarctica, B eijing Science Press, v. 3, p. 91- 105.

Received in J anuary, 2009; accepted in M ay, 2010. 